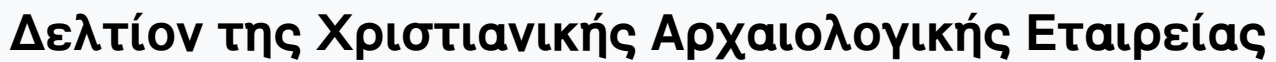

Tóp. 8 (1976)

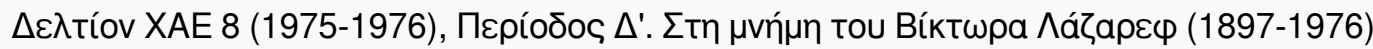

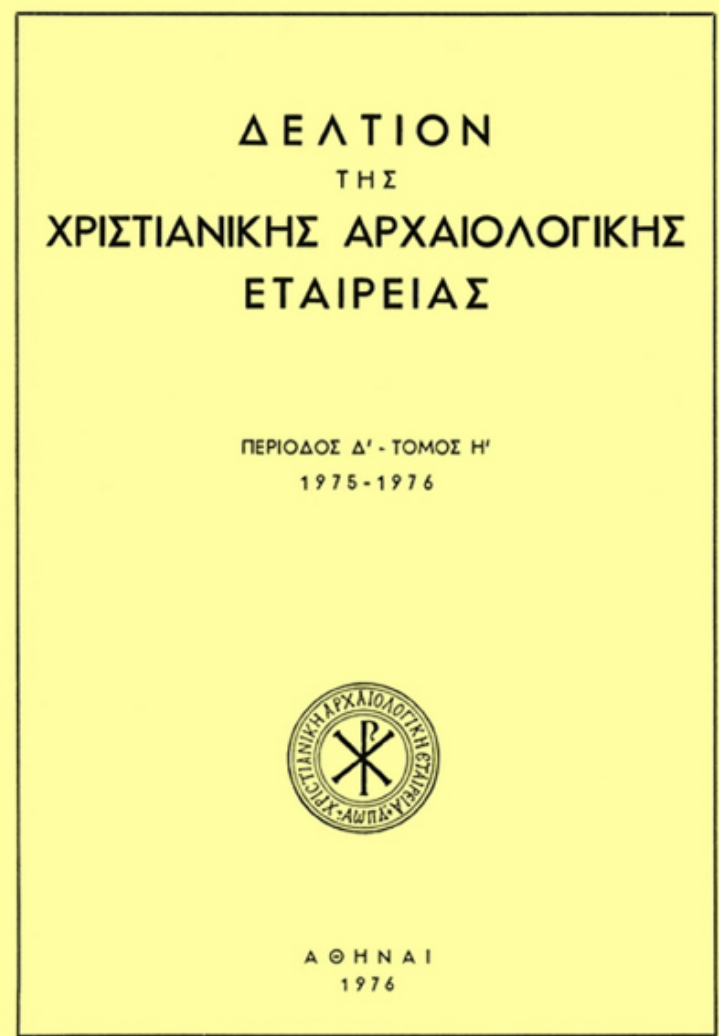

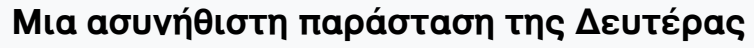

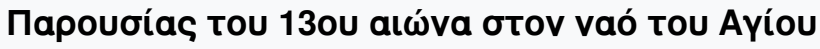

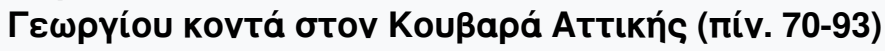

Doula MOURIKI

doi: $10.12681 /$ dchae. 854

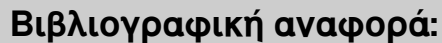

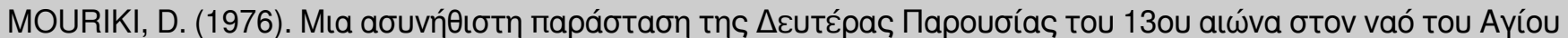

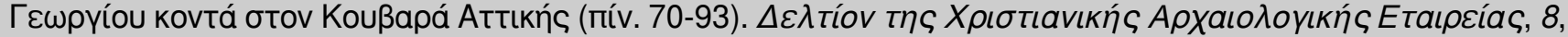
145-172. https://doi.org/10.12681/dchae.854 


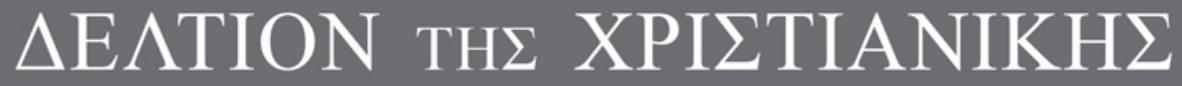 APXAIO $\Lambda$ OГIKH $\Sigma$ ETAIPEIA $\Sigma$}

An Unusual Representation of the Last Judgement in a Thirteenth Century Fresco at St. George near Kouvaras in Attica ( $\pi$ ív. 70-93)

Doula MOURIKI

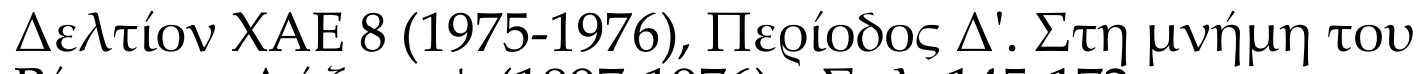

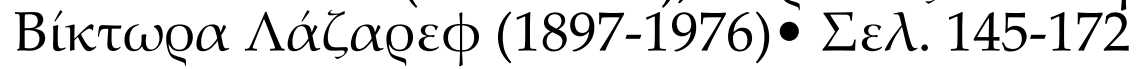

A@HNA 1976 


\title{
AN UNUSUAL REPRESENTATION OF THE LAST JUDGMENT IN A THIRTEENTH CENTURY FRESCO AT ST. GEORGE NEAR KOUVARAS IN ATTICA
}

\author{
( PL. $70-93$ )
}

A composition of the Last Judgment in fresco, which is preserved in the church of St. George near the village of Kouvaras in south-east Attica, constitutes one of the most interesting works of the thirteenth century in this area ${ }^{1}$.

The structural history of the small timber-roofed basilica (pls. 70 and 71, plan 1) belongs to different chronological phases ranging from the Early Christian to the Turkish periods ${ }^{2}$. The varied history of the building is also reflected in its painted decoration which is partly covered with whitewash. The large composition of the Last Judgment which will be the object of this study is situated on the upper part of the masonry screen of the Sanctuary. On account of its unusual iconographic and stylistic features, which betray

1. For some information on the architecture of the church see A. K. O r 1 a n d o s,

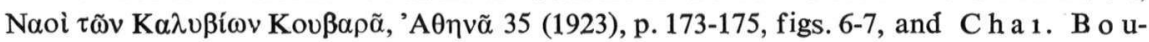
ras, A. Ka loyeropoulou, R. Andrea di, Churches of Attica, Athens 1970, p. 159-160, figs. 163-164, plan XX. A brief commentary on the thirteenth century fresco decoration at St. George will be found in M. C h a tzida kis, Aspects de la peinture murale du XIIIe siècle en Grèce, L'Art Byzantin đu XIIIe siècle. Symposium de Sotoćani 1965 , Beograd 1967, p. 66-67, figs. 10-12, and B o u r a s, Ka 1 o y e r o p o u l o u, A ndre a di, Churches of Attica, p. 160-161, fig. 167.

The photographs published here are from the Photographic Archive of the Byzantine Frescoes in Greece of the National Research Foundation; these are due to the photographers I. Ioannidou and L. Bartzioti. I wish to extend my thanks to Mr. M. Chatzidakis for giving me permission to publish the frescoes at St. George. These were cleaned under his supervision by the restorer Mr. F. Zachariou, in 1963. The photograph of the mosaic at Torcello (pl. 93a) is from Alinari, those of the Sinai icons (pls. 91 and 92) from the Photographic Archives of the Benaki and Byzantine Museums respectively. The photograph of the fresco at the Mavriotissa in Castoria is reproduced from the work by N. M o u t s op ou 1 os, The Monastery of the Virgin Mary Mavriotissa at Castoria, Athens 1967, pl. 53, and the drawing of plan 1 is due to $\mathrm{Ch}$. Bouras; it is reproduced from the volume by Bouras, Kaloyeropoulou, Andreadi, Churches of Attica, plan XX.

2. Ibid., p. 159-160. 
traces of Western influence, and of the uncommon disposition on the screen of the Sanctuary, this particular fresco sheds much light on the history of Byzantine painting in Attica during the thirteenth century.

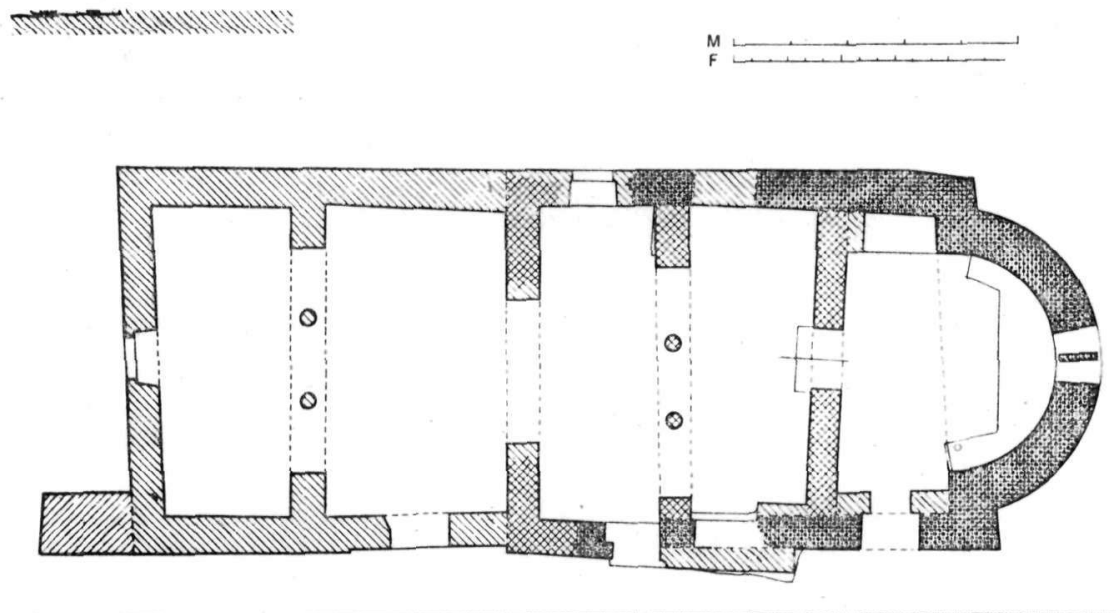

Plan 1.

The composition of the Last Judgment at St. George is contained within a single zone, namely, the one which usually constitutes the uppermost register in the traditional extended version of the scene ${ }^{3}$, as witnessed, for instance,

3. The main bibliography on the iconography of the Last Judgment is : N. P ok rovcky, Strašnij Suđ v pamiatnikach vizantijskogo i russkogo iskusstva, Truđi VI arkheologičeskogo cjezda v Odesse, 1884, III (Ođessa 1887), p. 285-381. G. V o s s, Das Jüngste Gericht in đer bilđenden Kunst đes frühen Mittelalters, Diss. Leipzig 1884, p. 64-75. A. G r a b a r, La peinture religieuse en Bulgarie, Paris 1928, p. 82-85. W. P a es e le r, Die römische Weltgerichtstafel im Vatikan. Ihre Stellung in der Geschichte des Weltgerichtsbildes und in đer römischen Malerei des 13. Jahrhunderts, Kunstgeschichtliches Jahrbuch der Bibliotheca Hertziana II (1938), p. 313-394. G. M i 11 e t, La dalma-

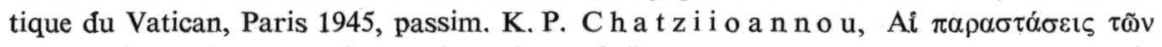

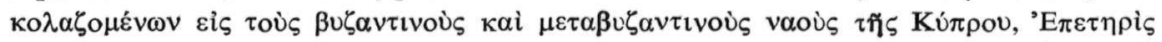

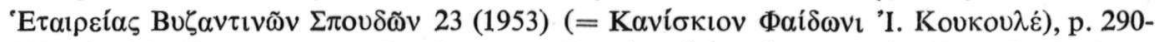
303. A. M. C oc a g n c c, Le Jugement Dernier dans l'Art, Paris 1955. L. Réa u, Iconographie de l'art chrétien II, 2, Paris 1957, p. 725-756. P. A. Un de rwood, Third Preliminary Report on the Restoration of the Frescoes in the Kariye Camii at Istanbul by the Byzantine Institute, 1956, Dumbarton Oaks Papers 12 (1958), p. 237-263. V. L a z a re v, Freski Staroj Lađogi, Moscow 1960, p. 48-53. D. M i 1 o s e vi ć, Das Jüngste Gericht, Recklinghausen 1963. B. Brenk, Die Anfänge der byzantinischen Weltgerichtsdarstellung, Byzantinische Zeitschrift 57 (1964), p. 106-126. I d e m, Tradi- 
in an eleventh-twelfth century icon at Sinai (pl. 91) ${ }^{4}$. The composition which stretches along the entire width of the screen has a triangular shape necessitated by the timber roof above; the width of the fresco is $5.30 \mathrm{~m}$. and the maximum height of the preserved surface of the painting $2.05 \mathrm{~m}$.

The central part of the scene of the Last Judgment, above the Holy Door, is occupied by the figure of Christ in a mandorla (pls. 72 and 73-74). Christ is depicted seated on a throne; both feet are placed on a cushion. He is represented in a frontal position with both hands extended on either side. His right hand, palm outwards (a feature indicative of acceptance), is directed towards the Righteous, whose depiction is traditionally associated with this side of the composition. Christ's words of blessing to the Elect (Matthew $25: 34)$ in fact appear in the half-effaced inscription below. On the contrary, Christ's left hand, with the palm turned down, symbolises a gesture of rejection aimed at the Damned, who are traditionally depicted on Christ's left side. Christ wears a brown chiton striated in yellow and a white-grey himation. The clavus and cuffs of his chiton are heavily decorated with pearls and vermiculation. The decorative approach to the figure is moreover observed in the contour of Christ's nimbus which bears an ornamentation of crosses inside lozenges, as well as in the elaborate wooden throne and the two cushions. The stiff red drapery with white ornaments which hangs from the top of the back of the throne harmonises perfectly with the white mandorla which is decorated with red stars.

Christ's figure forms, as always in the iconography of the Last Judgment, a Deisis with the figures of the Virgin on his right and St. John the Baptist on his left (pls. 73 and 74). Both figures turn towards Christ, their hands extended in supplication. The Virgin wears a dark blue chiton and a purple maphorion, while the Baptist is clad in a red brown chiton highlighted in yellow, and in an olive green mantle lined with sheepskin.

Christ's figure is framed by a large choir of angels symmetrically disposed. Two of them, depicted on either side of Christ, are partly hidden by the mandorla. Three more are represented from the waist or bust upwards, above Christ's head. The remaining members of the angelic choir are placed near the figures of the Virgin and the Baptist or at the back of the compo-

tion und Neuerung in der christlichen Kunst des ersten Jahrtausends. Studien zur Geschichte des Weltgerichtsbildes (Wiener Byzantinische Studien 3), Wien 1966, passim. K. P a p a d o p o u 1 o s, Die Wandmalereien đes XI. Jahrhunderts in der Kirche Mavaría $\tau \tilde{\omega} \nu$ X $\alpha \lambda \kappa \varepsilon \dot{\varepsilon} \omega \nu$ in Thessaloniki, Graz-Köln 1966, p. 57-76. P. A. U n d e r w o o d, The Kariye Djami, I (Bollingen Series LXX), New York 1966, p. 199-212. M. G a v ri 1 i s,

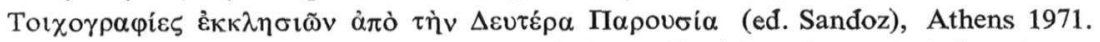

4. G. and M. S o t i r i o u, Icones du Mont Sinai, I, Athens 1956, fig. 151. 
sition. They are represented in full length, in half length or by the head alone, according to their place in the composition. The angels are clad either in imperial garments with the lori or in the customary attire of Byzantine court officials. They hold sceptres and globes. The decorative approach to these figures is observed in the diversified and vividly coloured garments as well as in the yellow, red and blue nimbi which surround their heads.

The scene of the Last Judgment is, as usual, complemented with depictions of apostles flanking the central group. On the right side of Christ and the Virgin and at a certain distance away from them so that sufficient space may be left for the inclusion of a pair of wheels («thrones»), St. Paul is depicted standing (pl. 75). He is turned slightly towards the central group, with his right hand raised in a gesture of supplication. The apostle is clad in the customary antique garb but does not hold the codex, his traditional attribute. Next to St. Paul, St. John the Evangelist is shown turned towards the central group. The upper part of the figure has suffered considerable damage, but the Evangelist's identity may be established with certainty by the physiognomical features, which are partly preserved, and by the last letters of the name wros. St. John raises his right hand in a gesture of blessing, while holding a closed Book of Gospels in the left. There follows a third apostle but his face and the inscription bearing his name are not preserved. He raises his right hand in the act of blessing and holds a closed Book of Gospels in the left. All three apostles are depicted standing in front of a synthronon which is elaborately decorated.

The symmetrical group of apostles on the left side of Christ also consists of three figures ( $\mathrm{pl} \mathrm{76)}$. The one nearest to Christ is St Peter, identified by his physiognomical features and by the keys he holds in his left hand. He is also depicted standing and turning slightly towards the centre; his right hand too is raised in a gesture of blessing. Next to St. Peter two other apostles hold closed Books of Gospels in both hands. Their heads are destroyed and the same applies to the inscriptions of their names. All three figures are also depicted standing in front of a synthronon.

The scene of the Last Judgment in the fresco at St. George also includes a series of figures of the Damned which are traditionally associated with it. In particular, a frieze consisting of one full length figure and nine heads fills a strip of red intended to represent the Stream of Fire which issues from the bottom of Christ's throne and extends across the right-hand side of the composition.

Beginning from left to right, we see first a nude man (pl. 85).

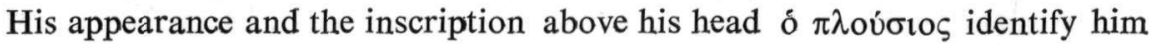


as the Rich Man in the parable of Lazarus mentioned in Luke $(16: 19-25)$. Seated among the flames, he is turning to the left in order to face Abraham and Lazarus who would have been depicted in Paradise on the opposite side had the scene been represented in its extended form. The Rich Man, who is touching his parched tongue with his finger, solicits Abraham to send Lazarus in order that he may dip the tip of bis finger in water and cool his tongue, as explained in the long inscription above the figure which is an

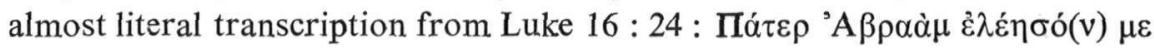

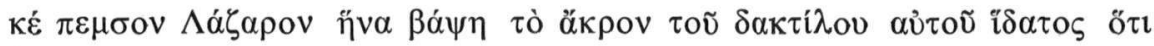

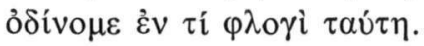

Near the figure of the Rich Man is a series of nine heads. These, except for one, are depicted in pairs and may be identified, for the most part, by the objects which hang from their necks and in each case reveal the nature of their sin and the cause of their damnation.

The first sinner on the left (pl. 86) is a man who cheats his customers when weighing goods (a feature rendered more explicit by the position of the balances). There follows a royal couple with no specific attributes (pl. 87). The Byzantine imperial crowns, which they wear, would be sufficient to characterize their crime as that of abuse of power and worldly vanity. The presence of holders of worldly power and material wealth is specifically underlined in depictions of the Last Judgment, as well as in related literature. In the eyes of the common people, this feature at least served as some sort of compensation for the unequal distribution of wealth and power in this world. The inscription above the head of the male royal figure in the fresco, however, explicitly identifies him as Herod ('O I ó $\delta \eta \zeta)$. His female companion would thus be none other than Herodias, the notorious mother of Salome.

Next follow two high ranking personages, who may be identified by their headdresses and the objects hanging frc $m$ their necks (pl. 88). The figure to

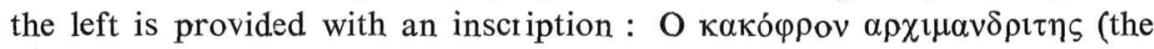
evil-minded archimandrite). He is, in fact, depicted attired in the black hood of a monk and he has a money-bag hanging from his neck. The attachment of the clergy to material wealth is in this way stigmatised.

The function of the figure next to the Orthodox archimandrite is more difficult to determine. He is depicted wearing a white cap with two streamers falling down on one side. The cause of his torment apparently lies in something he has written, as indicated by the kalamarin, i.e. the penholder and inkpot attached around his neck which a small black devil grasps. The figure might be identified by the white cap which he wears; but this feature characterizes a wide range of officials. Although it may not be entirely excluded from the 
vestments of the clergy ${ }^{5}$, in this instance, it is in all probability a part of the attire of a secular functionary, such as the figures accompanying the Emperor Nicephorus Botaneiates in a miniature of the Homilies of St. John Chrysostom in the Bibliothèque Nationale (Coisl. 79, Fol. 2) ${ }^{6}$. The personage with the white cap and the kalamarin in the fresco at St. George may well be someone whose decisions affected the people in an abusive way, either by the imposition of taxes or through some other unpopular enforcement of power. On the other hand, the possibility that the official represented here was somebody involved in forging legal documents, a current custom in the Middle Ages, cannot be entirely excluded.

The last four of the Damned in the fresco represent persons who were punished for having committed offences of a rural character. The agricultural instruments hanging around their necks point to this identitication. The first man was responsible for having ploughed another man's field, as indicated by the yoke around his neck (pl. 89). The second man harvested in another man's field (pl. 89); the sickle around his neck indicates the nature of his offence. The third man, depicted with a hatchet, was responsible for cutting wood in someone else's property (pl. 90). The last, equipped with a large pair of shears, may have been guilty of trespassing in a garden in order to cut branches (pl. 90).

After the identification of the iconographic elements of the Last Judgment in the fresco at St. George, it may be worthwhile discussing a number of unusual features which provide this work with a special place in the iconography of the scene. It is well known that this composition, which epitomises the main Christian concepts regarding the Divine scheme of human salvation, is not based on a single source of inspiration. Evangelical passages, especially from St. Matthew, the Apocalypse of St. John, a homily of Ephraim the Syrian, and the liturgy have provided the main elements for the iconography of the subject. Despite the variety and profoundly allegorical nature of these textual sources, the pictorial expression of the Last Judgment almost invariably retained a number of standard themes which remained unchanged throughout the Byzantine period. These include : the central Deisis group as the nucleus of the composition; the choir of angels around Christ; the twelve apostles seated on either side of the central group,

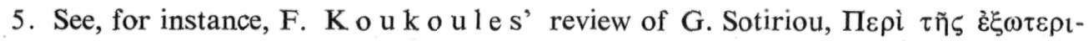

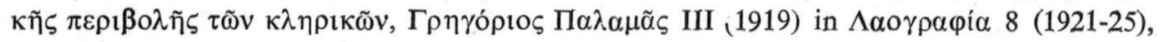
especially p. 249, 258.

6. H. O m o n t, Miniatures des plus anciens manuscrits grecs de la Bibliothèque Nationale đu VIe au XIVe siècle, Paris 1929, p. 33, pl. LXIII. 
and various categories of Elect and condemned figures appropriately disposed on either side of the composition. The fully developed iconography of the Last Judgment appears in Byzantine art from the eleventh century onwards, as observed in the extant pictorial material ?. Moreover, the expansion of the iconographic elements of the scene has led to its arrangement either in a multi-register composition on a plane surface or in a three-dimensional space made possible by the use of the upright and curved surfaces in churches. In monumental painting both these types were usually reserved for a specific area in the church, i.e. the western part, and more precisely, the narthex.

No striking iconographic deviations from tradition need be pointed out regarding the central figure of the Last Judgment in the fresco at St. George (pl. 72). Christ's seated position and the gestures he makes are in conformity with the traditional rendering of the scene ${ }^{8}$. By contrast, two different ways may be observed regarding the place where Christ is seated. At St. George, as in most instances, Christ is seated upon a throne which may refer to the "throne of his glory)" (Matthew 25:31). In some examples, however, Christ is depicted sitting on the arc of heaven, as in the scene of the Ascension ${ }^{9}$.

7. The earliest dated example of the Last Judgment in Byzantine art is the fresco at Ayvali Kilise (913-920) in Cappađocia. See N. and M. Th i e r r y, Ayvali Kilise ou pigeonnier đe Gülli Dere, église inédite đe Cappađoce, Cahiers Arrchéologiques XV (1965), fig. 24. Among the earliest examples of the scene in Byzantine art, reference may also be made to the miniatures in the Cosmas of the Vatican (Vat. gr. 699, Fol. 89) and the Sacra Parallela (Paris. gr. 923, Fol. 68v), the dates of both of which can be ascribed to the late ninth century. An early example of the scene in monumental painting is also to be found in the fresco in the narthex of St. Stephen in Castoria which has been dated on stylistic grounds

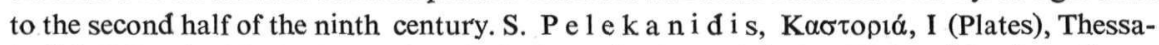
loniki 1953, pls. 87-88. B r e n k, Die Anfänge đer byzantinischen Weltgerichtsđarstellung, op. cit., p. 106-126. On the other hand, the earliest literary evidence for the existence of the subject in pictorial form is probably the reference in Theophanes Continuatus (tenth century) to an icon of the Last Judgment painted by a Greek artist which was instrumental in the conversion of King Boris of Bulgaria to Christianity (in 864). I. B e k ke r, CSHB, p. 163-164. Cf. C. M a n g o, The Art of the Byzantine Empire 312-1453 (Sources and Documents). Edited by H.W. Janson, Englewood Cliffs, N.J. 1972, p. 190-191. However, the preserved pictorial evidence regarding the Last Judgment scene indicates that the complete iconographic development of the scene was not achieved before the eleventh century. See Karoline Papadopoulos Kreidls review of Brenk's Tradition und Neuerung, op. cit., in Jahrbuch đer Österreichischen Byzantinistik XVI (1967), especially p. 345 .

8. Christ is depicted in the act of blessing with his right hand in some examples of the scene of the Last Judgment, probably under the impact of the traditional iconography associated with his pictorial representations.

9. For the depiction of the arc of heaven in the scene of the Last Judgment another passage from Matthew $(24: 30)$ may have provided the inspiration. 
Another characteristic feature in the scene is the mandorla which surrounds Christ's figure. The elliptical mandorla in monochrome, as at St. George, is more common in the eleventh and twelfth century representations of the Last Judgment (Sant' Angelo in Formis, Torcello, Neredica, the Crypt of Backkovo) ${ }^{10}$, while in the later monuments Christ's glory usually has a circular shape and consists of concentric zones of different tones of blue ${ }^{11}$. A further detail in Christ's mandorla in the fresco is its wavy contour. Although Christ's glory is depicted with undulating contours, which vaguely recall those of the mandorla at St. George ${ }^{12}$, in a few Byzantine representations of the Last Judgment and of the Ascension, this feature is, on the whole, closer to Western depictions ${ }^{13}$.

The inclusion of a large choir of angels in a closely knit group, forming a "glory» around Christ, as in the fresco at Kouvaras, appears very early in the iconography of the scene ${ }^{14}$. The same applies to the triadic group of angels above Christ's head ${ }^{15}$. The colourful diversified garments of the angels, intended to indicate the various heavenly orders in accordance with the texts (Matthew 25:31), are also noted in other examples of this scene ${ }^{16}$.

The depictions of the Virgin and the Baptist conform to a long-standing tradition in so far as their posture and position in the scene are concerned. On the other hand, the depictions of the apostles in the fresco at St. George

10. Cf. G r a b a r, Peinture religieuse, op. cit., p. 83 .

11. Ibid., p. 83 note 7. A circular glory in the scene is also observed in the eleventh century fresco of the Panaghia ton Chalkeon. See Byzanz und der Christliche Osten, Propyläen Kunstgeschichte 3 (1968), pl. IX.

12. See, for instance, the scene of the Last Judgment in the frescoes at Ayvali Kilise, Cappadocia. Th i e r r y, Ayvali Kilise, op. cit., fig. 24, and the unpublished composition of the Ascension in the recently uncovered eleventh century frescoes in the church of St. Nicholas tis Stegis at Kakopetria, Cyprus.

13. See, e. g., a miniature of the Last Judgment in the thirteenth century Lectionary Helmst. 65 of Wolfenbüttel, Fol. 13v. G. C a mes, Byzance et la peinture romane de Germanie, Paris 1966, fig. 270.

14. The feature in question appears in the Carolingian fresco of Müstair which reveals traces of the influence of a Byzantine representation of the Last Judgment. See B r e n k, Die Anfänge der byzantinischen Weltgerichtsđarstellung, op. cit., p. 118-119.

15. The same feature is, for instance, observed in the eleventh century miniature of the John Climacus manuscript in the Vatican (Cod. gr. 394, Fol, 12v). J. R. M a r t i n, The Illustration of the Heavenly Ladder of John Climacus, Princeton N.J. 1954, fig. 73. For this particular device in Byzantine art, see A. G r a b a r, Influences byzantines sur les peintures murales de Civate, in Arte in Europa. Scritti di Storia dell'Arte in onore di Edoardo Arslan, Milan 1966, p. 279-280.

16. See, for instance, the fresco of the Mavriotissa at Castoria. M o u t s o p o u los, Mavriotissa, pls. 41 and 42. 
reveal several important deviations from tradition. Reference is made to their posture, number and the disposition of SS. Peter and Paul in relation to Christ.

The seated posture of the apostles becomes canonical for the scene of the Last Judgment, as this is firmly based on Matthew 19:28. And Jesus said unto them, Verily I say unto you that ye who have followed me, in the regeneration, when the Son of man shall sit on the throne of his glory, ye also shall sit upon twelve thrones, judging the twelve tribes of Israel. This approach is not, however, observed in the fresco at St. George. Here the apostles are represented standing, and only the elaborate synthronon at the back recalls the evangelical passage. The standing position of the apostles in the scene of the Last Judgment, combined with the restriction of their number as in the fresco at St. George - six figures are here represented instead of the canonical twelve-has, in so far as I know, only one parallel in the iconography of the Last Judgment. Reference is made to the fresco in the small church of St. Nicholas near Kalamos in eastern Attica which may be dated towards the end of the thirteenth century ${ }^{17}$. The restricted number of the apostles in the scene of the Last Judgment of the two small churches in Attica, together with their standing postures, require an explanation which cannot be solely connected with the narrow space available in both instances. These two deviations from tradition in the iconography of the Last Judgment constitute typical features associated with another composition, the so-called Great Deisis, whose content is related with that of the Last Judgment. It is probable that the transformation of the scene in the fresco at St. George was effected under the impact of a Great Deisis composition, as will be explained later.

The leading members of the group of apostles on either side of Christ in the fresco at St. George are easily identifiable as SS. Peter and Paul, the princes among the apostles, who invariably occupy the same positions in all known examples of the scene of the Last Judgment. On the other hand, the four remaining figures in the fresco may be identified with certainty as the four evangelists (pls. 75 and 76), as furthermore indicated by the inscrip-

17. Bouras, Kaloyeropoulou, Andreadi, Churches of Attica, p. 360 ff. Of the Last Judgment scene only a detail of an apostle has been published. Ibid., fig. 335 .

The painted decoration of the church includes a fragmentary depiction of the Last Judgment on the south wall of the narthex. Only the figures on the uppermost register have been partly preserved, but it is evident that the scene originally included more than one zone of episodes. Here, the figures of the Supreme Judge, the Virgin, St. John the Baptist and angels are flanked by six standing apostles, three on either side. 
tion accompanying the figure of St. John depicted next to St. Paul. In fact, the inclusion of the evangelists in the traditional group of the twelve apostles - SS. Luke and Mark did not form part of the original group - goes back to the Early Christian period ${ }^{18}$. In addition, the prominence given to the evangelists vis-à-vis the rest of the apostles may also be established from an early period ${ }^{19}$.

Regarding the two (koryphaeoi» among the apostles, no explanation is needed to justify their prominent positions in the scene of the Last Judgment, as this also applies to many other compositions in which the presence of the apostles is required. In the context of the Last Judgment, however, a more precise reason may be found in the fact that both figures were associated with eschatological visions, as indicated by the so-called Apocalypses of St. Peter and St. Paul.

The only pertinent observation concerns the exact relationship of the two apostles to the figure of Christ. St. Peter, as is well-known, usually occupies the place of honour on the right side of Christ, having thus been given prominence over St. Paul who takes the second most important place on the left of the Supreme Judge. This, however, is not the case in the fresco at St. George where we note a reversal in the position of the two apostles. The same feature may be observed in several pictorial examples of the Last Judgment. The relevant list includes the fresco in the Panaghia ton Chalkeon in Thessaloniki (1028) ${ }^{20}$, one of the two illustrations of the scene in the late eleventh century Paris Book of Gospels (Bibliothèque Nationale, gr. 74, Fol. 93v) ${ }^{21}$, the fresco in St. George at Staraya Ladoga, Russia, of the late twelfth century ${ }^{22}$ and the late eleventh century fresco in the Georgian church of Ateni ${ }^{23}$. The reversal of the positions of the two apostles

18. In connection with this question see $\mathrm{M}$. S a c o p o u lo, La Théotokos à la mandorle de Lythrankomi, Paris 1975, p. 43-48.

19. Ibid., p. 47-48. An important attestation is contained in Nicholas Mesarites' Ekphrasis of the Church of the Holy Apostles at Constantinople. G. D o w n e y, Nikolaos Mesarites : Description of the Church of the Holy Apostles at Constantinople, Transactions of the American Philosophical Society (Philadelphia 1957), p. 867-868, 900.

20. Papadopoulos, Wandmalereien, op. cit., p. 61.

21. O m o n t, Évangiles avec peintures, op. cit., pl. 81.

22. L a z a r e v, Freski Staroj Lađogi, op. cit., p. 49, figs. 62 and 63.

23. P a p a dopoulos, Wandmalereien, op. cit., p. 61. The reversal of the positions of SS. Peter and Paul is noted in three thirteenth century works in Italy, namely a panel painting in the Vatican ( $\mathrm{P}$ a e s e le r, Römische Weltgerichtstafel, op. cit., p. 314, fig. 271; P a pado p o ulos, Wandmalereien, op. cit., p. 61), the fiesco in the chapel of St. Silvester in the Church of the Quattro Coronati in Rome (ibid.) and the fresco by Pietro Cavallini in the Church of St. Cecilia in Trastevere, Rome (F. H e r m a n i n, L'Arte in Roma đel sec. VIII al XIV, Bologna 1945, pl. CLVIII). 
in the fresco at St. George, which assigns St. Paul precedence over St. Peter, does note in my opinion, seem accidental, as we shall presently explain.

The depictions of St. Paul in Byzantine art usually conform to the iconographic tradition regarding his portraiture which goes back to the first centuries of Christianity ${ }^{24}$. Thus, the baldness of the figure, the long semitic nose and dark hair and beard are properly emphasized. In the fresco at Kouvaras these features are not particularly stressed, and a notable deviation from tradition is the apostle's grey hair ${ }^{25}$. A further iconographic anomaly is the omission of St. Paul's customary attribute, the Book of Gospels. The same omission, but in the context of a depiction of a Great Deisis, may be observed in a Crusader icon on Mount Sinai (pl. 92). Here, as is also the case in the fresco at St. George in Attica, the artist adopted the gesture of supplication from the preceding figure, in this case St. John the Baptist, and endowed St. Paul with it ${ }^{26}$.

Regarding the depiction of St. Peter in the fresco ${ }^{27}$ only one feature needs special mention : namely, the two keys on a ring which the apostle holds in his left hand (pl. 76). The keys doubtless constitute one of the most important attributes of St. Peter, connected as they were with his role as the guardian of the Gate of Paradise ${ }^{28}$. Although the keys appear in association with St. Peter as far back as the Early Christian period, both in the East and the West ${ }^{29}$, this particular feature, while becoming a common attribute of the apostle in Western art throughout the mediaeval period, remains very rare in Byzantine art until the thirteenth century ${ }^{30}$. Nevertheless, the keys

24. For the iconography of St. Paul, see J. F i c k e r, Die Darstellung der Apostel in der altchristlichen Kunst, Leipzig 1887, passim. E. v o n D o b s c h ü t z, Der Apostel Paulus. Seine Stellung in der Kunst, 1928.

25. It is extremely rare to find a depiction of St. Paul as grey-haired in Byzantine art. One example does, however, occur in a thirteenth century unpublished fresco in the Metropolis at Veria. I owe this information to Mr. E. Tsigaridas.

26. Cf. K. W e i t z m a n n, Four Icons on Mount Sinai : New Aspects in Crusader Art, Jahrbuch đer Österreichischen Byzantinistik 21 (1972), p. 283, fig. 1.

27. For the iconography of St. Peter, see H. B r in k m a n n, Die Darstellung des Apostels Petrus, Düsseldorf 1936.

28. For the attributes of St. Peter, see R é a u, Iconographie, III, p. 1083.

29. A notable example in the East is the encaustic icon of St. Peter on Mount Sinai. See K. W e it z m a n n, et al., A Treasury of Icons, New York 1966, p. X, LXXIX, pl. 5.

30. Among the rare examples of the depictions of St. Peter holding the keys of Paradise in Byzantine works prior to the thirteenth century, see the fresco of the Ascension at Kurbinovo (1191). L. H a d e r m a n n - M i s g u i c h, Kurbinovo. Les fresques de Saint-Georges et la peinture byzantine du XIIe siècle, Bruxelles 1975, fig. 82; also the unpublished portrait of the saint in the Church of the Panaghia of Arakas, at Lagoudera, Cyprus (1192). 
reappear in the East from that period onwards and may in this case be attributed to Western influence. This feature may consequently be noticed in : a) a group of Crusader icons on Mount Sinai ${ }^{31}$, and b) a group of fresco decorations in Attica and neighbouring areas, and all of the Frankish period; the latter group includes the frescoes at the Church of St. Peter at Kalyvia ${ }^{32}$, in the Omorphi Ecclesia near Athens ${ }^{33}$ and the Omorphi Ecclesia on the island of Aigina ${ }^{34}$.

The iconography of the scene of the Last Judgment at St. George represents a conflation of pictorial elements, included in the uppermost and lower registers in the traditional rendering of the scene. The frieze with the Damned, which is depicted directly below the apostles in the right-hand part of the fresco, would thus have found a place at the bottom of a multiregister representation of the scene.

Of the Damned the first figure on the left, i.e. the Rich Man in the parable of Lazarus (pl. 85), constitutes an isolated element in the frieze of the tortured figures in Hell. This figure alone is depicted full length in a posture which becomes banal in the various examples of the scene of the Last Judgment, thus indicating the old and firmly established tradition of the theme ${ }^{35}$. The constant depiction of the Rich Man who did not care for the needy of this

31. See K. W e i t z m a n n, Thirteenth Century Crusader Icons on Mount Sinai, Art Bulletin 45 (1963), p. 193, fig. 17. I d e m, Icon Painting in the Crusađer Kingdom, Dumbarton Oaks Papers 20 (1966), p. 65, figs. 31 and 33. I d e m, Four Icons, op. cit., p. 283 , fig. 1 .

32. St. Peter holding the keys forms part of the group of the Elect in the scene of the Last Judgment (west wall of the narthex).

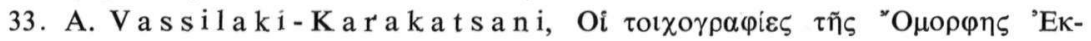

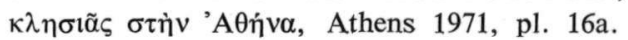

34. The keys are held by St. Peter in the scene of the Ascension. See Ch a tzid a k i s, Aspects đe la peinture murale đu XIIIe siècle en Grèce, fig. 25.

35. The Rich Man is depicted in the same fashion as in the fresco at Kouvaras in the following instances: Fresco of the Panaghia ton Chalkeon (1028) : P a p a d o p o u$1 \mathrm{os}$, Wandmalereien, op. cit., p. 65. The two miniatures in the Paris Gospel 74, Fols. 51v and 93v (eleventh century) : $\mathrm{O} \mathrm{m}$ o $\mathrm{nt}$, Évangiles avec peintures, op.cit., pls. 41 and 81. The two eleventh-twelfth century icons on Mount Sinai : S o t i riou, Icones, op. cit., figs. 150 and 151. Cf. pl. 91 of the present study. Fresco of the Church of St. Nicholas tis Stegis (twelfth century) : Unpublished. The Rich Man is here labelled by mistake "the Rich Lazarus". Fresco in the Church of the Episkopi in the Mani (twelfth century) : N.

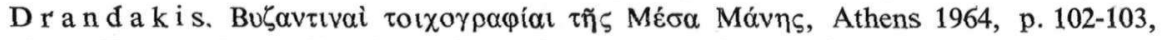
pl. 83. Fresco of the Church of the Saviour at Neredica (1199) : V. L a z a r e v, Old Russian Murals and Mosaics, London 1966, fig. 104. Ivory in the Victoria and Albert Museum (probably twelfth century) : Late Antique and Byzantine Art, Victoria and Albert Museum, London 1963, fig. 46. 
world in the representations of the Last Judgment conforms with the mentality of mediaeval society in which philanthropy was a key concept.

Unlike the instance of the Rich Man, the remaining figures of the Damned as symbols of particular types of sin need a more detailed examination, for they reflect a more particular approach. The first figure beside the Rich Man, i.e. the man whose crime was the falsifying of weights (pl. 86), is often included among the Damned in the depictions of the Last Judgment. Among the relevant examples of the Byzantine period, the fresco at the Mavriotissa in Castoria (pl. 93b) ${ }^{36}$, those in the narthex of the Panaghia of Asinou (1332/ 1333) ${ }^{37}$ and of the Panaghia Ljeviška in Prisren (early fourteenth century) ${ }^{38}$, as well as a fresco in the church of Ai Stratigos at Boularioi in the Mani ${ }^{39}$ may be mentioned. The motivation for the illustration of this particular sin in Byzantine depictions of the Last Judgment reflects a common problem of the period ${ }^{40}$. On the other hand, the standard apocryphal texts (such as the so-called Apocalypse of the Virgin), which contain lively accounts of the various tortures in Hell witnessed by privileged personages, make specific mention of this particular $\sin ^{41}$.

Were it not for the inscription identifying the male royal figure in the fresco at St. George as Herod (pl. 87), it would be hardly necessary to justify the presence of a royal couple among the Damned in Hell. The reversal of conditions between this world and the other constitutes a recurring theme in theological literature ${ }^{42}$. Thus the inclusion of royalty among the permanent

36. On the south wall of the narthex a man, depicted hanging upside down with the

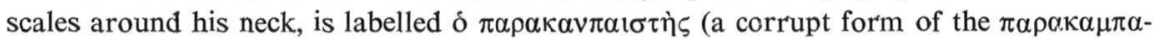

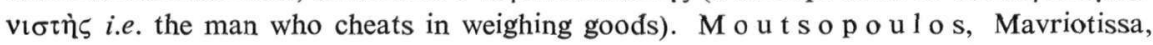
op. cit., p. 39 , pl. 53.

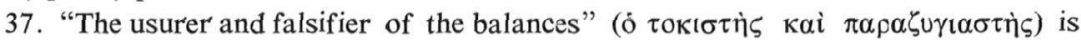
depicted among the Damned on the eastern soffit of the southern arch of the narthex. A. and J. Stylianou, Panagia Phorbiotissa, Asinou, Nicosia 1973, p. 66. Cf.

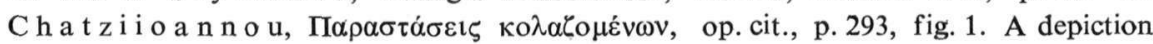
of the falsifier of balances is also depicted in the late frescoes of the Antiphonitis in Cyprus. Ibid., p. 296, fig. 5.

38. D. Pa nić and G. Ba bić, Bogorodica Ljeviška, Beograd 1975, pl. XLVI.

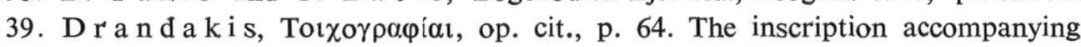
the figure is $\pi \alpha \rho \alpha \kappa \alpha \mu \pi \alpha v 1 \sigma \tau \eta \dot{s}$. The fresco of the Last Judgment in this church has been dated to the thirteenth-fourteenth century.

40. In some instances, the man who cheats in the weighing of objects is labelled the miller; this feature makes the milieu that favoured similar representations more precise.

41. See H. Pernot, Descente de la Vierge aux Enfers d'après les manuscrits grecs de Paris, Revue đes Études Grecques 13 (1900), p. 252.

42. See, for instance, the liturgy of the Funeral Service which emphasizes the fact that death has the same power over rich and poor alike. G o a r, Euchologion, Venice 1730 (Photostatic impression Graz 1960), p. 432. 
guests of Hades is a common feature in the iconography of the Last Judgment ${ }^{43}$. However, the identification of the king with Herod in the church of St. George at Kouvaras adds a new dimension to the interpretation of these particular royal figures. This identification may be based on a firmly established popular tradition which presents Herod as the great exemplum of human cruelty ${ }^{44}$. The obvious fact that the most cruel among men happens to be a king helps to stigmatise both conditions at the same time. On the other hand, the Apocalypse of the Virgin does specifically name Herodias, (the murderess of St. John the Baptist», as a distinguished client among the tortured in the Underworld ${ }^{45}$. This allusion may probably account for the depiction of the «lascivious Herodias) in the eighteenth century frescoes of the metropolitan church of St. John in Nicosia ${ }^{46}$. The same apocryphal text may also account for the specific identification of the royal male figure in the fresco at St. George.

The inclusion of high-ranking representatives of the clergy in the pictorial examples of the Last Judgment constitutes a common feature of the iconography of the scene ${ }^{47}$. The special interest of the depiction of the archimandrite in the fresco at St. George (pl. 88) derives from the fact that his $\sin$ is specifically identified (by the money-bag hanging around his neck) as that of attachment to material wealth. Here we then have a case of direct pictorial criticism of a vice common among the clergy, as witnessed by various texts ${ }^{48}$; the association of the money-bag with a

43. The list of the pictorial examples of the Last Judgment including royalty among the Tormented in Hell is endless. See, e.g., the mosaic at Torcello (pl. 93a).

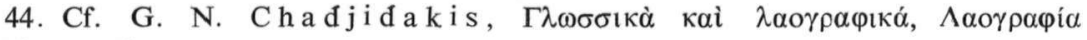
7 (1923), p. 92.

45. See M. Gi de1, Étude sur une Apocalypse đe la Vierge Marie, Annuaire de l'Association pour l'Encouragement des Études Grecques en France 5 (1871), p. 97.

46. See Chatziioa nno u, П $\alpha \rho \alpha \sigma \alpha \dot{\sigma \varepsilon \varepsilon \varsigma \varsigma ~ \kappa o \lambda \alpha \zeta o \mu \varepsilon ́ v \omega v, ~ o p . ~ c i t ., ~ p . ~} 298$.

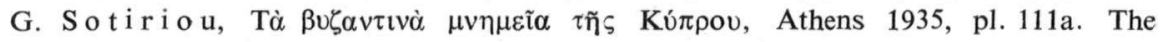

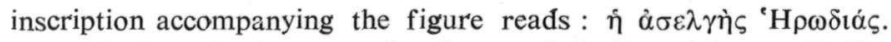

47. See, for instance, the fresco of the Panaghia ton Chalkeon. P a p a d o p o u$10 \mathrm{~s}$, Wandmalereien, op. cit., p. 62. The miniature of the Paris Gospel 74, Fol. 93v. Omont, Évangiles avec peintures, op. cit., pl. 81. Mosaic at Torcello (pl. 93a). Fresco in the Parecclesion of Kariye Djami. U n d e r w o o d, The Kariye Djami, I, p. 206; III, pl. 391.

48. A very lively criticism of the clergy which occupies a distinguished place in Hell occurs in the Vit a of Basil the Younger, a tenth century ascete from Constantinople. A passage in one of the manuscripts, the Paris. gr. 1547, dated 1286, which was communicated to me by Miss Christina Angelidi who is preparing a doctoral thesis on this Vita

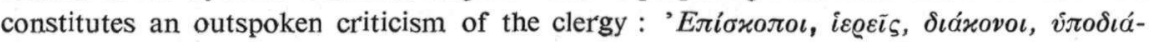

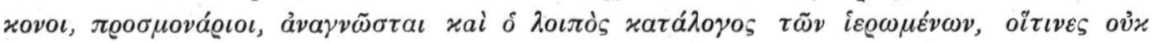


representative of the Byzantine clergy has not, however, in so far as I know any other parallel in Byzantine art ${ }^{49}$.

In addition to royalty, representatives of secular power, usually identified by ingenious light-coloured headdresses, are often included in depictions of the Last Judgment in Byzantine art ${ }^{50}$. Special interest is attached to the depiction of the layfigure in the fresco at St. George by the kalamarin which provides an allusion to the nature of the crime committed by the figure in question (pl. 88). This feature too, in so far as I know, has no parallel in the relevant pictorial material in Byzantine art.

The agricultural implements which characterize the last four sinners in the fresco at Kouvaras provide this group with a homogeneous character which was absent in the previous examples. The first figure from the left (pl. 89) is depicted with a yoke hanging round his neck and

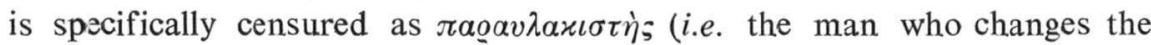
boundaries of the fields and ploughs another man's land) in some pictorial examples of the Last Judgment. The frequent occurrence of this type in the art historical material implies that this transgression must have been very common in small rural societies. The same feature is, for instance, observed in the churches of Ai Stratigos at Boularioi in the Mani ${ }^{51}$, of the Panaghia at Asinou in Cyprus ${ }^{52}$, and of the Virgin Ljeviška at Prisren, in Yugoslavia ${ }^{53}$.

The man who harvests in another man's field (pl. 89) appears to be less popular among the Damned in Hell. The same type may be found in the

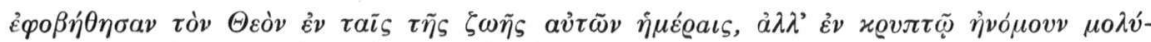

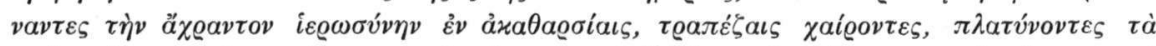

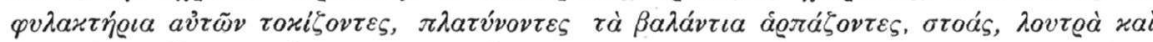

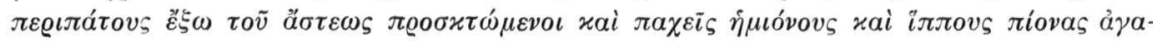

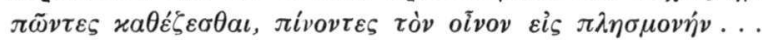

49. In Byzantine art, the money-bag often becomes a characteristic attribute of a related type of sinner, namely the usurer, who is frequently included among the Damned in Hell. See, for instance, the fresco of the Mavriotissa at Castoria (pl. 93b). Moreover depictions of money-bags lying on the ground with coins falling around are sometimes connected with the representation of the Rich Man in the iconography of the Last Judgment. See, e.g., the fresco in the Parecclesion of Kariye Djami. U n de rwood, The Kariye Djami, I, p. 209; III, pl. 397.

50. See, for instance, the fresco of the Panaghia ton Chalkeon. P a p a d o p o u 1 os, Wandmalereien, op. cit., p. 62. Paris gr. 74, Fol. 93v. O mo n t, Évangiles avec peintures, pl. 81. Mosaic at Torcello (pl. 93a).

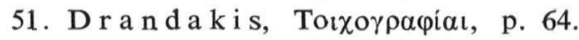

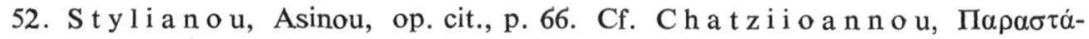

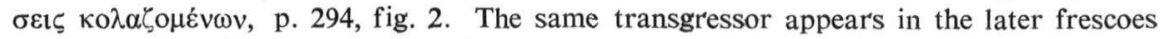
of the Antiphonitis in Cyprus. Ibid., p. 296-297.

53. Panić and Babić, Bogorođica Ljeviška, op. cit., pl. XLVI. 
fresco of the Last Judgment of Ai Stratigos at Boularioi in the Mani ${ }^{54}$, and is also mentioned in the Apocalypse of the Virgin ${ }^{55}$. On the other hand, the presence of the two remaining transgressors in the fresco at St. George, notably the man with the hatchet and the one with the pruning shears (pl. 90), has not been traced in the relevant pictorial material of the Byzantine period.

In order to gain a thorough understanding of the meaning of this particular frieze with the Damned in the fresco at St. George, a brief survey of this class of figures in Byzantine art may be found useful. In fact, the presence of various categories of the Damned may be detected in the earliest preserved examples of the fully developed iconography of the scene of the Last Judgment, such as the fresco in the Panaghia ton Chalkeon, the two miniatures in Paris. gr. 74, the two well-known icons on Mount Sinai (pl. 91) etc. In so far as I know, no specific attributes indicating the particular crimes committed in each case appear in the earlier representations of the scene in Byzantine art. Only the vestments identify the various categories of the Damned as royal figures, secular dignitaries, bishops, monks and infidels. A good example of this approach is provided by the mosaic at Torcello (pl. 93a).

The Damned are usually depicted as a mixed group driven into the fire by one or more angels. A different approach is represented by the inclusion of small rectangular compartments, ranged one beside the other in one or two superimposed registers. Both examples may co-exist in the same scene, as observed in the mosaic at Torcello. It is significant to note that in both cases only heads or busts are visible, the rest of the body being submerged in the fire.

A third approach is illustrated by the depiction of full-length figures which are standing or are hanged, sometimes upside down; these are usually either tortured by devils in the flames or encircled by snakes. It is again possible that this particular type may co-exist with the two previous ones in the same work.

It is difficult to say which of the three ways of representing the Damned in Hell reflects the earliest stage in the iconographic evolution of the scene of the Last Judgment. In the earlier examples only the sex of the figures provides some indication as to the nature of the sin; for instance, nude women encircled by snakes are usually meant to represent prostitutes. On the other hand, the specific types of sinners are eventually made known by the inscriptions which accompany the figures. A somewhat early example of this ap-

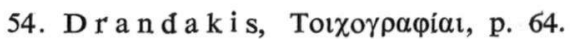

55. See Pernot, Descente de la Vierge, op. cit., p. 252. 
proach is provided by the frescoes at Yilanli Kilise in Cappadocia; these have been dated to the ninth or first half of the tenth century ${ }^{56}$.

As noted earlier, the idea of characterizing the figures of the Damned in Hell by the instruments of their sin hanging round their neck has not been detected in the early Byzantine representations of the scene of the Last Judgment. The earliest example is probably the one in the fresco in the narthex of the Mavriotissa at Castoria (pl. 93b). It is true that the painted decoration of this church constitutes an enigmatic ensemble in so far as its dating is concerned. The two divergent views regarding the dating of these frescoes (reference is made to the interior decoration only) point, on the one hand, to the late eleventh-early twelfth century ${ }^{57}$ and, on the other, to the early decades of the thirteenth century ${ }^{58}$. Regardless of this controversy, the view may be held that we here have the earliest instance of the inclusion of the instruments of sin hanging from the necks of the Damned in Byzantine art. The second relevant example is probably the one in the fresco at St. George at Kouvaras.

The feature of the instruments of sin hanging from the necks of the Damned enjoyed wider popularity in later periods. Among the fourteenth century examples the frescoes in the Church of the Virgin Ljeviška at Prisren (early fourteenth century), those in the narthex of the church of Asinou (1332/1333) and in the church of the Ascension at Dečani (ca. middle of the century) ${ }^{59}$ may be mentioned. During the post-Byzantine period the custom of introducing large groups of tormented people in Hell in the depictions of the Last Judgment becomes even more common and the same is true with regard to the additional feature of the instruments of $\sin { }^{60}$. It is worth noting, however, that, regardless of age, the attributes of sin are always combined with full-length figures. In this respect, the fresco at St. George represents one more deviation from tradition.

56. See N. and M. Thierry, Nouvelles églises rupestres de Cappadoce, Paris 1963, p. 100-101, 114, pl. 50a.

57. See $\mathrm{S}$. P e le k a n i d is, I più antichi affreschi di Kastorià, Corsi di Cultura sull' Arte Ravennate e Bizantina 11 (1964), p. 361-366.

58. See $\mathrm{Ch}$ a tzidakis, Aspects de la peinture murale đu XIIIe siècle, op. cit., p. $64-65$.

59. The Virgin Ljeviška : P a ni ć anđ B a bi ć, Bogorođica Ljeviška, op. cit., pl. XLVI. The Virgin of Asinou : S t y li a n o u, Asinou, op. cit., p. 66; The Church of the Ascension at Dečani. A detail of the scene is included in $\mathrm{O}$. B i h a lji- Me rin, Byzantine Frescoes and Icons in Yugoslavia, New York 1958, fig. 62.

60. Very few of the relevant examples have so far been published. For' a characteristic post-Byzantine example, see the fresco in the catholicon of the Monastery of Seltsu in Epirus (dated 1697). P. Vocotopoulos in A $\Delta$, Xpovikò 22 (1967), p. 357, pls. 265-266a. 
Despite the fact that the instruments of sin, as seen in the churches of the Mavriotissa and St. George, have not been detected in the earliest Byzantine examples of the scene of the Last Judgment, the popular expression that the crime of a man may hang from his neck follows, in all probability, a very old tradition. Thus, the Chronicon of Georgios Amartolos (ninth century) includes a satirical account of the personality of Mohameth, in which a characterization of his controversial personality is given. The text specifically refers to the illusion he harboured of being the guardian of Paradise. But, instead of letting the Righteous enter the Gate and leave the Damned outside, he does the opposite. The relevant passage describes the

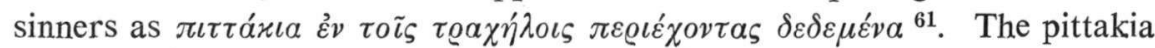
may well have assumed the form of inscribed tablets hanging around the necks of the sinners.

It is worthwhile casting a brief glance at the approach of Western art towards this particular question. Artists in the West, as is well-known, favoured a great development in the depictions of the Last Judgment, since they conformed to the moralising aims of this particular artistic expression. Thus, in the first place, Western theologians agreed that sinners are punished by means of the instruments of their lust ${ }^{62}$. Moreover, as far back as the early twelfth century, at least one figure in some monumental sculptured façades of the Romanesque cathedrals in France recalls the special group of the Damned which are observed in Byzantine representations of the Last Judgment, as seen at St. George. We refer to the figure of Avaritia, characterized by a money-bag attached round her neck, as for instance shown in the south vestibule of Saint-Pierre at Moissac ${ }^{63}$. Notwithstanding these examples, it is somewhat difficult to infer the impact made by one pictorial tradition on the other, since both appear to depend on common textual sources which may go back to a very early period.

A survey of the sins associated with the Damned in the depictions of the Last Judgment during the Byzantine and post-Byzantine periods reveals a fairly standard repertory of themes. The most popular figures are the p. 701.

61. Georgii Monachi Chronicon (edit. C. de Boor), II, Leipzig 1904 (Teubner),

62. Cf. A. Katzenelle n boge n, Allegories of the Virtues and Vices in Mediaeval Art, London (The Warburg Institute 1939) (Kraus reprint 1968), p. 58 note 3.

63. Cf. B. Rupprecht, Romanische Skulptur in Frankreich (ed. Hirmer), Munich 1975, pl. 42. It may also be noted that a man with a money-bag hanging from his neck is included among the Damned in the scene of the Last Judgment, sculptured in the tympanon of the west vestibule of Sainte-Foy at Conques. This depiction may refer to the "cupidoi" mentioned in the accompanying inscription. Ibid., pls. 114-115, 119. 
falsifier of weights, the dishonest miller, the man who ploughs another man's field, the usurer, the blasphemer, those who sleep late on Sunday and do not go to church, prostitutes, adulterers, monks and nuns who have broken their vows, the woman who refuses to nurse her child, and so on. All these themes would not necessarily require a special textual justification for their representation in art, since they formed part of the everyday experience of the people of those times ${ }^{64}$. However, the common mediaeval approach which reveals a great amount of flexibility in matters of copying and of plagiarism may probably imply that, even in ordinary cases such as those of the standard representations of the tormented figures in Hell, painters reverted to textual sources and model books in order to copy themes and particular details.

The basic textual sources for the Torments in Hell consisted of the popular literature referring to the Underworld. Among the earliest relevant texts the three Apocalypses under the names of the Virgin, St. Peter and St. Paul may be mentioned. Unlike the Apocalypses of St. Peter and St. Paul, which appear to have originated in the very early centuries of Christianity, that of the Virgin is a later production, based mainly on the Apocalypse of St. Paul ${ }^{65}$. All these apocryphal texts, which had a powerful popular appeal, provide vivid accounts of the various categories of sinners and the torments deemed fitting for them. The verisimilitude of these accounts gains weight in the light of the fact that these experiences were witnessed by highly privileged individuals in the Christian hierarchy. The tedious phraseology encountered in these texts was meant to excite popular imagination. Fire, snakes and infernal pits are proper media for the punishment of those who transgressed religious and moral laws. In some cases special degrees of depth are mentioned in relarion to the fire or the pit which engulfs the sinners in conformity with the seriousness of each particular transgression. The submergence of the condemned figures up to the neck, as those at St. George at Kouvaras, would thus reflect a somewhat extreme state of guilt.

Popular literature of this kind usually stigmatises moral and religious vices and is specially aimed at the clergy and the powerful persons of this world. The emergence of a standard selection of sins both in the texts and in Byzantine and post-Byzantine art indicates their interrelation. Despite

64. The point is made clear in the codifications of offences in the various handbooks of civic and penal law, as, for instance, in the four teenth century Hexavivlos of Constantine Armenopoulos which is based on earlier legal literature.

65. A critical edition of these apocryphal texts has not yet been published. For some information on them, see M. R. J a m e s, The Apocryphal New Testament, Oxford 1926, p. 563 and passim. 
the homogeneous approach to the depictions of the Damned in Hell in the Byzantine examples of the Last Judgment, the choice of the particular sins illustrated in each case may provide some indication as to the milieu for which the specific decoration was executed. Thus the predominance of the rural misdeeds at St. George indicates in all probability the non-monastic, agricultural background of the unknown donor of the fresco decoration.

The iconographic study of the scene of the Last Judgment in the fresco at St. George reveals important deviations from tradition which are particularly evident at the two ends of the composition and which include the figures of the apostles and the Damned in Hell. A stylistic analysis of the fresco also reveals a discrepancy between the central part and the two ends, especially in relation to the scale and the bodily types of the figures. The composition does not thus diminish gradually towards the ends, as required by the triangular shape of the surface available for the scene and in accordance with hierarchical considerations. Here, the three figures emphasized by their scale and the distance lying between them are not Christ, the Virgin and St. John the Baptist, i.e. the Deisis group proper, but Christ, St. Peter and St. Paul. An explanation for the adoption of this feature may probably be found in the use of more than one model for the execution of this composition which must have been the work of a single painter. The lack of an iconographic model with a similar non-canonical rendering of the scene of the Last Judgment, as observed at St. George, may add additional weight to this hypothesis. The use of different models for the make-up of a new composition is also suggested in the style of the fresco.

The fresco of the Last Judgment at St. George was briefly discussed by $\mathrm{M}$. Chatzidakis in his survey of monumental painting in Greece during the thirteenth century at the Symposium at Sopoćani. In this context the work was dated to about the mid-thirteenth century and its dependence on the Comnenian tradition was duly emphasized ${ }^{66}$. In fact, the most obvious observation one can make in regard to the style of the figures in this fresco is the two-dimensional impression which they convey. Christ's body, for instance, has a flat appearance which is enhanced by the extensive use of highlights on his chiton and by the intricate folds of his himation. The slender throne on which Christ sits and the small mandorla surrounding him increase this two-dimensional impression. Another noteworthy feature is the relatively small size of Christ's body in comparison with the large

66. Chatziđakis, Aspects đe la peinture murale đu XIIIe siècle en Grèce, op. cit., p. 66-67. 
head, hands and feet. A flat approach is also noticeable in the depictions of the Virgin, St. John the Baptist and the angels surrounding the main group. The central part of the composition does not therefore reveal the major interest shown by thirteenth century painters in the plasticity of the human body and the exploitation of spatial relations. Several figures of the apostles, however, show a rather strong feeling for plasticity in the rendering of the bodies and a monumental appearance.

This observation becomes even more apparent in the depictions of St. John the Evangelist and the apostle behind him (pl. 75). St. John's body is rather robust, properly emphasized by the rendering of the drapery and the pose in a three-quarter view. Moreover, the figure of the apostle behind St. John, although represented in an almost frontal position, again conveys a three-dimensional impression, as indicated by the breadth of the body and the strong contrapposto.

Unlike the two apostles, the other figures in this group are rendered in a more conservative fashion, the eclectic style of the fresco being thus revealed. For instance, the contrapposto in the figure of St. Paul (pl. 75) is not well rendered and the linear treatment of the drapery indicates a mechanical application of the standard devices of ancient art. A similar approach is apparent in the depiction of St. Peter (pl. 76).

An eclectic approach is also noticeable in the modelling of the faces. Although devoid of carelessness or lack of skill, the artist's work does reveal a remarkable freedom in the brushwork which enhances the expressionistic appearance of the figures. This approach, however, is used in a discreet way for the more hieratic figures, especially those of Christ and the angels, while applied with greater emphasis in the faces of the Baptist and the apostles and, even more so, in those of the tormented figures in Hell.

The modelling of the faces is executed in red and ochre. Red is applied in the form of freely-shaped touches on the cheeks, especially in the depictions of St. Paul, of the Baptist and the angels, but acquires a more appropriate function on the tormented faces of the sinners in the Stream of Fire, where it conveys something of the feverish atmosphere of the Underworld. The red touches on the faces recall a common stylistic device in eleventh and twelfth century painting. This feature continued to be used in a great number of works of the thirteenth century, but became remarkably rare in the succeeding periods. Red touches are, for instance, used in the thirteenth century frescoes of St. Peter at Kalyvia and of the Chapels at Penteli.

Despite the free handling of the brushwork and a flexible use of red and black for stressing certain features, as in the case of the Damned in Hell, there is a certain absent-minded quality on the faces which is conveyed by the 
rolling eyes. This feature is particularly apparent in the depictions of St. Paul (pl. 83), the Baptist (pl. 82) and the Damned in Hell. St. Paul's face, for instance, has an ecstatic look and a suave expression which do not recall the alert and expressive portrait of the great intellectual of the Church, as encountered in numerous representations of the apostle in Byzantine art. In the case of St. John the Baptist the rolling eyes are even more emphasized. This feature, combined with the pathetic expression and a somewhat unconventional rendering of the physiognomical traits, provide the figure with a special place in the portraiture of the Baptist in Byzantine art. In fact, the rolling eyes are more in keeping with the stylistic conventions of works on which Western art made a strong impact, such as a large group of Crusader icons on Mount Sinai ${ }^{67}$.

The impression of a certain absent-mindendness is also noticeable on the faces of the Virgin (pl. 81) and of several angels (pl. 80). This vacant look is also encountered on the faces of the tormented figures in Hell. In the case of the latter, in particular, the rolling eyes and contracted eyebrows are correctly emphasized to indicate psychic tension and physical pain.

The expressive quality of the style of the fresco at St. George is furthermore revealed in the free nervous use of the black lines and shaded areas beneath the eyes. The heavy black contours which encompass the figures also indicate the painter's linear approach. This basic characteristic of Comnenian style is apparent in the ornamental treatment of the garments, attributes, and various pieces of furniture. A distinct taste for decorative effects is, in particular, encountered in the imitation of precious stones and costly materials. A case in point is the garb of the angels surrounding Christ's mandorla. The embroidered and pearl-studded garments of this group have rarely received a similar ornamental treatment in the depictions of the Last Judgment as in the one at St George. A somewhat related case is observed in the representations of the scene at St. Peter at Kalyvia in Attica and in the Mavriotissa at Castoria ${ }^{68}$.

The distinct taste for ornamentation which characterizes the fresco at St. George may, moreover, be detected in two additional features, notably the contour of Christ's nimbus (pl. 77) and the decorated clavus of the chiton

67. See W e i t z m a n n, Thirteenth Century Crusader Icons on Mount Sinai, op. cit., p. 189. I d e m, Four Icons, op. cit., p. 281.

68. The frescoes of St. Peter at Kalyvia have been studied in N. C o u m b a r a k iP a n séli n ou, Deux monuments đu XIIIe siècle en Attique : L'église de Saint-Pierre de Kalyvia-Kouvara et la chapelle de la Vierge de Mérenta (thèse de đoctorat de troisième cycle), Paris 1971. This study is actually in press. For the scene of the Last Judgment in the Mavriotissa at Castoria, see Mouts op oulos, Mavriotisa, pls. 41 and 42. 
of several figures (pl. 76 and 77). Both features are often encountered in provincial works of the thirteenth and fourteenth centuries in Greece ${ }^{69}$.

The most obvious aspect of the ornamental approach to the fresco at St. George is revealed in the depiction of the synthronon behind the apostles. Although it acquires a luxurious aspect in other representations of the Last Judgment ${ }^{70}$, nowhere else has the synthronon become such an elaborate piece of refined workmanship embellished with precious stones and other decorative features. In this fresco it looks like a perforated diaphragm provided with four superimposed rows of slender balustrades. The elaborate quality of the furniture is again in keeping with Comnenian taste ${ }^{\mathbf{7 1}}$.

The brilliant quality conveyed by the fresco at St. George is enhanced by the bright colours. Red and purple, in particular, are largely used for the angels' garments, for some features in the setting (e.g. the drapery falling down from the back of Christ's throne) and for the depiction of the Fiery Stream. Red serves indeed as a unifying element in the composition.

In this context special mention may be made of the use of red, blue and yellow nimbi for the angels' choir. Coloured nimbi, usually red and blue, are not a rare feature in Byzantine art, especially during the Middle Byzantine period ${ }^{72}$. Fairly frequently they characterize angels when depicted in large groups, as in the scene of the Last Judgment. Among the relevant examples, one may mention the depictions of the scene in the Panaghia ton Chalkeon ${ }^{73}$, at St. Demetrius in Vladimir ${ }^{74}$, in the Mavriotissa at Castoria ${ }^{75}$ and St. Peter at Kalyvia ${ }^{76}$.

69. For the decoration of the nimbi see, in particular, $\mathrm{T}$. V e $1 \mathrm{~m}$ a n s, Deux églises byzantines du đébut đu XIVe siècle en Eubée, Cahiers Archéologiques XVIII (1968), p. 199. On the other hand, the decorated clavus of the chitons is, for instance, encountered in the fresco of the Transfiguration at the Omorphi Ecclesia in Aigina (1284).

70. Cf. the fresco of the Mavriotissa at Castoria. Mo ut s o p o u los, Mavriotissa, pls. 41 and 42.

71. See, e.g., the throne of the Evangelist Mark in the Four Gospels of the British Museum (Burney 19, Fol. 1v). Catalogue of the Exhibition : Byzantine Art, An European Art, Athens 1964 (2nd edition), No. 314 (ill.).

72. For the feature of the coloured nimbi in Byzantine and Romanesque painting, see $\mathrm{G} \mathrm{r} \mathrm{a} \mathrm{b} \mathrm{a} \mathrm{r,} \mathrm{Influences} \mathrm{byzantines,} \mathrm{op.} \mathrm{cit.,} \mathrm{p.} \mathrm{280-281.} \mathrm{For} \mathrm{some} \mathrm{examples} \mathrm{of} \mathrm{the} \mathrm{use}$ of coloured nimbi in Byzantine painting, see i d e m, Peinture religieuse, op.cit., p. 38.

73. See Byzanz und der Christliche Osten, Propyläen Kunstgeschichte 3 (1968), colour pl. IX.

74. See V. Plugi n, Frescoes of St. Demetrius' Cathedral, Leningrad 1974, reproduction.

75. Personal observation.

76. See the forthcoming publication of the frescoes by N. Panselinou. Among the examples of a later period the unpublished fresco of Ai Stratigos at Boularioi in the 
The fresco of the Last Judgment at St. George retains the basic characteristics of the Comnenian style which survived in provincial monuments long after the end of the Comnenian period itself ${ }^{77}$. The fact that we are dealing with a work of the thirteenth century can be well established by a comparison of this fresco with other monumental paintings in Attica which may be fairly accurately dated on the basis of epigraphic or other documentary evidence.

The date of only one of the known fresco decorations of the thirteenth century in this area is preserved. We refer to the frescoes in the Cave of Penteli dated to the year $1233 / 1234{ }^{78}$. This ensemble preserves an additional feature for the purpose of dating: namely, the portrait of Michael Choniates, the last metropolitan of Athens who was forced to leave the town after the Frankish occupation of 1204 . The representation of Michael with a nimbus indicates that this is a posthumous portrait; the death of the metropolitan occurred around 1222. The evidence of the inclusion of a portrait of Michael Choniates in the frescoes of another church in Attica, at St. Peter at Kalyvia, acquires an even greater value, for these frescoes are not dated. Furthermore, on account of a close stylistic and iconographic affinity between these frescoes and the painted decoration of the Chapels at Penteli, the date of the former may be ascribed to about $1233 / 1234$.

The fresco of the Last Judgment at St. George at Kouvaras presents many stylistic affinities with the frescoes in the two foregoing monuments. All three works possess the same predilection for decorative effects, a marked preference for vivid colours, a non-painterly approach and an expressive handling of the line. With a few exceptions, all three works are heavily indebted to the stylistic conventions of the Comnenian period and appear to be almost entirely unaffected by the new tendencies towards a monumental style and

Mani and that of Ljutibrod, Bulgaria, may be mentioned. For the latter see $\mathrm{Gr}$ a b a r, Peinture religieuse, op. cit., p. 226-227.

77. For this retrospective tendency of the thirteenth century style in provincial monuments, see V. J. D j u r i ć, La peinture murale byzantine : XIIe et XIIIe siècles, XVe Congrès International d'Étuđes Byzantines. Rapports et Co-Rapports. III. Art et Archéologie, Athens 1976, p. 41 and passim.

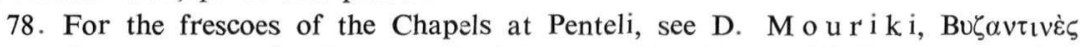

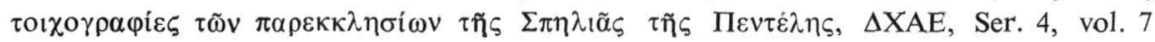
(1973 - 74), p. 79ff.

A different tendency in the style of thirteenth century frescoes in Attica is represented by a further group of monumental ensembles, two of which, notably, those of the Hagia Triada at Kranidi in Argolis (1244) and of St. John Kalyvitis at Psachna in Euboea (1245), are found in neighbouring areas; according to a dedicatory inscription, the former was executed by a certain Ioannis of Athens. 
a free painterly approach which may be observed in the most progressive ensembles of the period, such as the one at Mileševa.

On the basis of these observations, it is reasonable to assign a date to the fresco at St. George which would approximate to the fourth decade of the thirteenth century or slightly later. It is nevertheless worth noting the superior quality of the fresco at St. George, as compared to those at St. Peter and in the Chapels at Penteli. The expressive handling of the line and the elaborate modelling of some figures reveal a more expert painter who was in good command of the subtleties of the older Comnenian style.

The fresco decorations of the three small monuments in Attica have in common a further ideological affinity, which provides an insight into the religious climate prevailing in the area during the first phase of the Frankish period ${ }^{79}$. We refer to the special honour attributed in one way or the other to SS. Peter and Paul. In the Church of St. Peter at Kalyvia we find a more convincing evidence of this aspect. It may be recalled, in the first place, that the church was originally dedicated to the two apostles and not just to St. Peter as it is now ${ }^{80}$. Moreover, in an epigram discovered recently in the narthex, after the removal of the whitewash, special homage is paid to the two princes among the apostles, the true pillars of the Church ${ }^{81}$. If we consider that St. Peter is the saint of the Western church par excellence, while St. Paul is the apostle of the Gentiles and that the ties of the latter with Greece in particular have been very close, the dedication of the small church in Attica to SS. Peter and Paul, as well as the newly discovered epigram, may be viewed in a special light. All these features were most probably meant to smooth out the differences between the local community and the Franks who established themselves in the area after 1204. In the Chapels at Penteli, on the other hand, the medallions of SS. Peter and Paul were depicted on either side of a Deisis group which occupied the uppermost area over the conch of the Sanctuary ${ }^{82}$. The inclusion of these two portraits in such an important place may also be connected with considerations similar to those which may have dictated the exalted role of the two apostles in the Church of St. Peter at Kalyvia.

In the fresco at St. George we are faced with a slightly different case. SS. Peter and Paul were given special prominence in the composition

79. For a brief survey of the history of Attica during the earlier phase of the Frankish occupation, see Coumbaraki-Pansélinou, Deux monuments du XIIIe siècle en Attique (in press).

80. Ibid.

81. See the forthcoming publication of the above thesis.

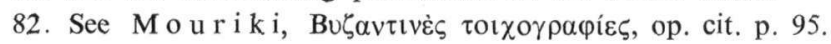


of the Last Judgment, as indicated by their size. Moreover, the abbreviated form of the scene and the restriction of the number of the apostles to six make the importance of the two leading members in this group all the more evident. It may also be noted here the particular role of SS. Peter and Paul as intercessors on behalf of mankind before Christ, a role which becomes apparent in their posture and gestures. A notable feature is the fact that St. Paul was given the first place in importance on the right of Christ, while St. Peter took the second on Christ's left. This can hardly be accidental, and would seem to indicate a particular wish on the part of the local donor to pay special homage to the apostle of the Greeks. By the omission of several themes which belong to the standard iconography of the Last Judgment and by the emphasis made on those which were taken over from it three main concepts are particularly stressed : a) Christ's role as the Supreme Judge; b) the important role of SS. Paul and Peter as intercessors for mankind; c) the assured punishment of all those who transgressed moral and ethical laws regardless of social and religious status.

It seems very probable that the transformation of the iconography of a typical scene of a Last Judgment, as depicted at St. George, so that it emphasizes the foregoing concepts, was effected under the impact of a composition of a Great Deisis. A depiction of this subject, as, for instance, observed in a Crusader icon on Mount Sinai (pl. 92), does not include any narrative elements. In it the Deisis group proper (Christ, the Virgin and the Baptist) is expanded so as to include angels, apostles and eventually other saints. On account of its content and also because of formal considerations, the composition of the Great Deisis had already found a place at the top of the screen of the Sanctuary from an early period ${ }^{83}$.

A composition of the Great Deisis may also have motivated the unprecedented disposition of the Last Judgment on the screen of the Sanctuary at St. George, which has, to my knowledge, no other parallel in art. Both the compositions of the Last Judgment and the Great Deisis possess, as is wellknown, an eschatological content which is in keeping with the meaning of the programme in the Sanctuary ${ }^{84}$. On the other hand, the prominent position assigned to the scene of the Last Judgment in this small church in Attica may probably indicate the funerary function of the building. On account of

83. Cf. M. Chatzidakis, Ikonostas, Reallexikon zur byzantinischen Kunst, III, Stuttgart 1973, col. 348.

84. For the eschatological content of the Deisis and its association with the programme of the Sanctuary, see A. G r a b a 1, Les peintures murales dans le choeur de Sainte₹ํ. phie đ'Ochrid, Cahiers Archéologiques XV (1965), p. 264. 
the oblong and narrow space, the small basilica seems rather inappropriate for accomodating a parish congregation. The use of the place for burials may in addition be supported by the various layers of painting preserved in the church. These comprise, for the most part, portraits whereas the inclusion of several invocations from various persons provides them with a devotional character ${ }^{85}$. In case the small church of St. George were used for funerary purposes, the removal of the scene of the Last Judgment from the west part of the church, where it traditionally belongs, to the east makes perfect sense ${ }^{86}$, since the scene would epitomise the iconographic programme of a local serving for burials.

The special importance of the fresco of the Last Judgment at St. George in the context of the history of artistic production in Attica during the Frankish period need hardly be stressed. It is precisely the conflation and, to a certain degree, the confusion of iconographic and stylistic elements, apparent both in the small details which were taken over from Western art, and in the readaptation of old themes to new purposes and meanings, that reflect the new state of affairs : the shocking effect made by the Frankish occupation in the religious and cultural life of the small rural society of Attica.

DOULA MOURIKI

85. See Bouras, Kaloyeropoulou, Andreadi, Churches of Attica, p. 160-161. It may also be pointed cut that an eighteenth century fresco of the Last Judgment decorates the west wall of the narthex at St. George.

86. A related instance is encountered in the Funerary Parecclesion of Kariye Djami at Constantinople. 


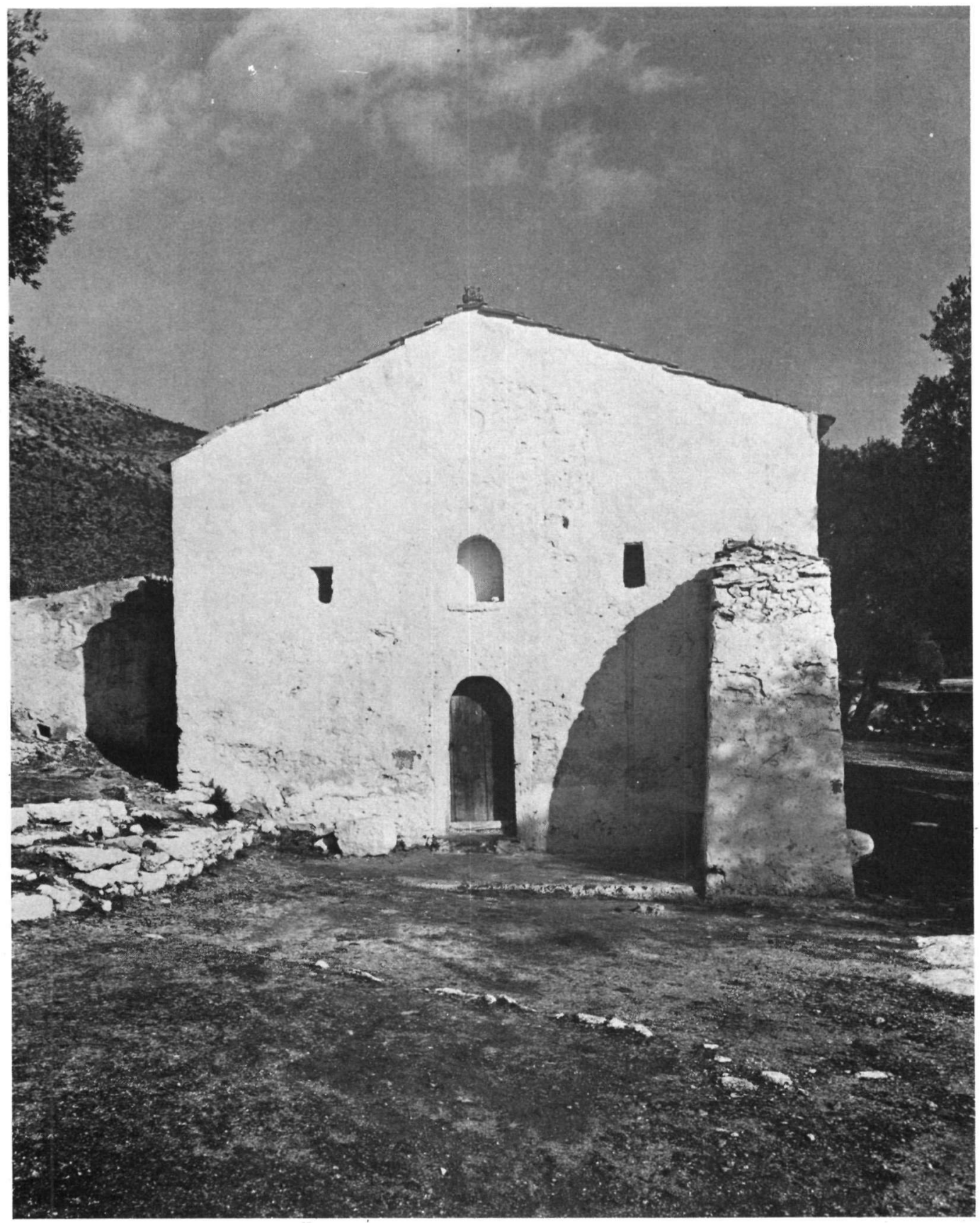

St. George at Kouvaras. View from the West. 


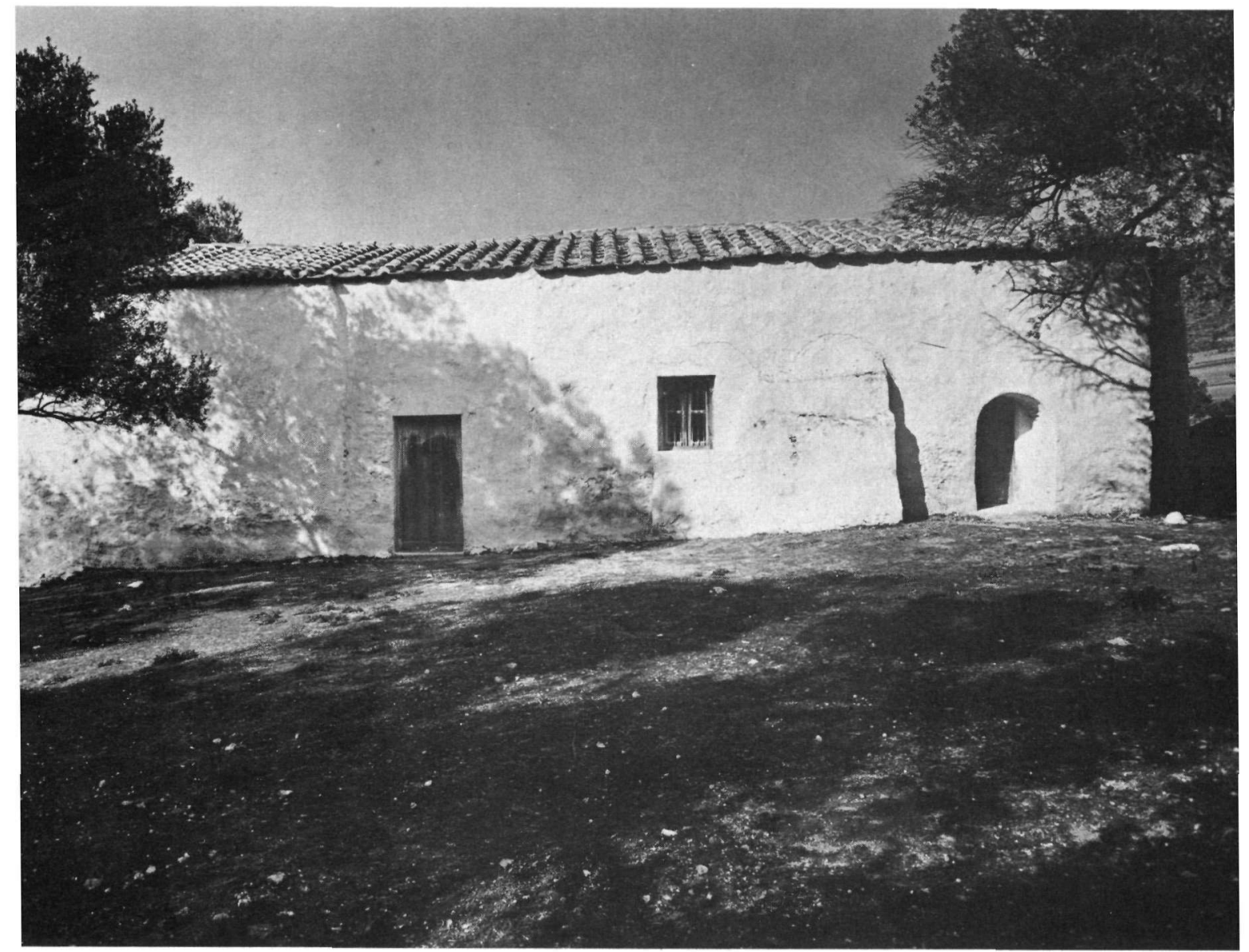

St. George at Kouvaras. View from the South. 


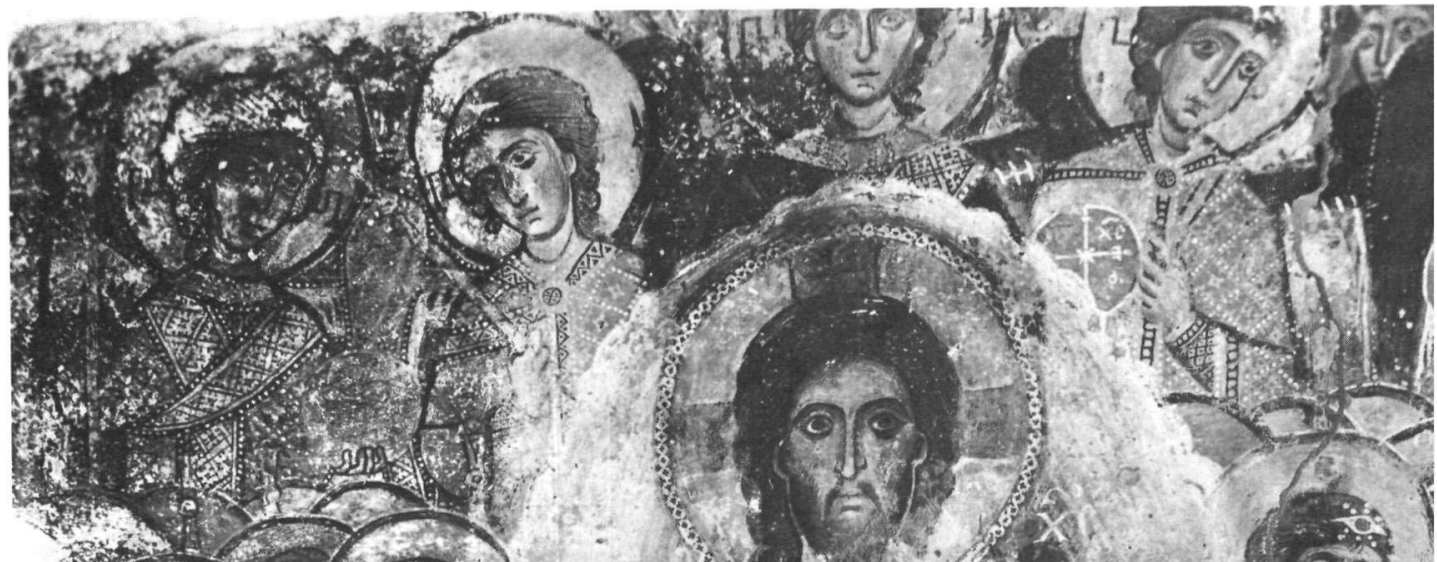

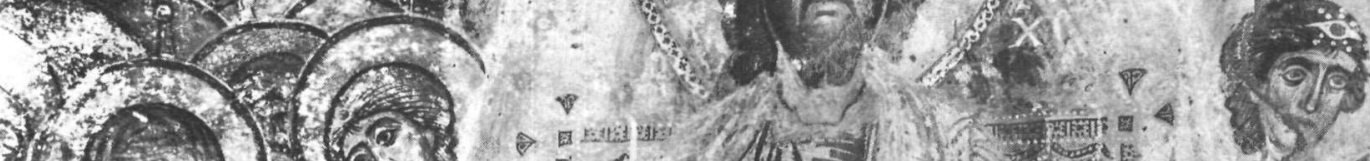

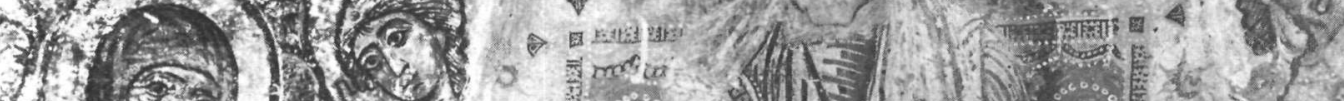

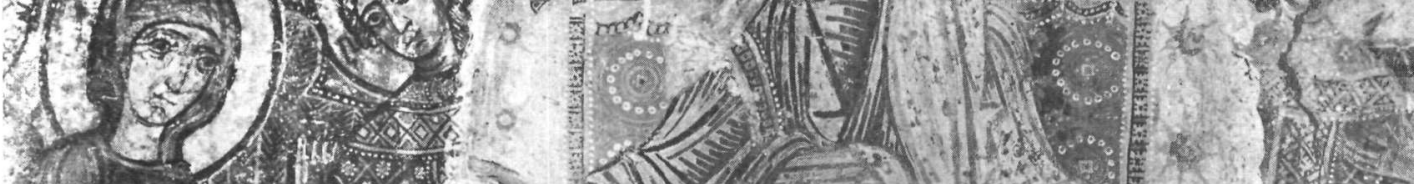

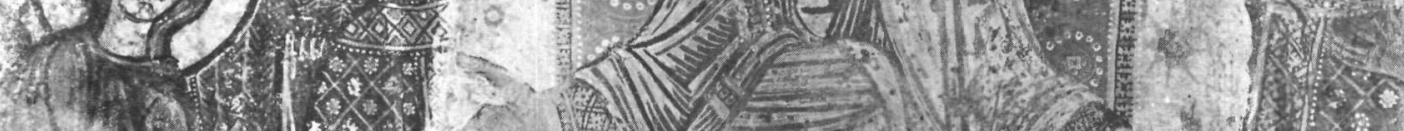

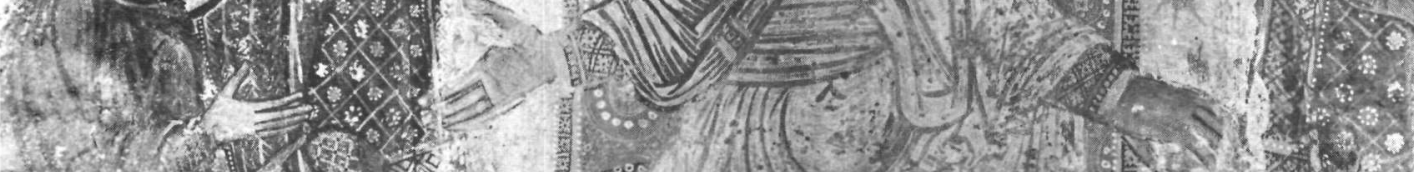

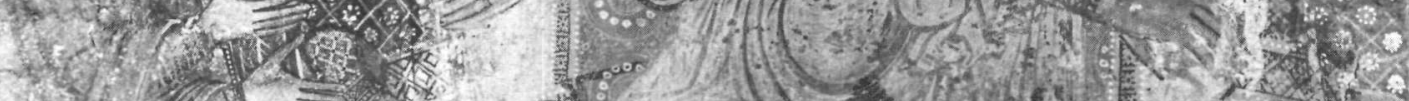
30 (1) 1 (1)

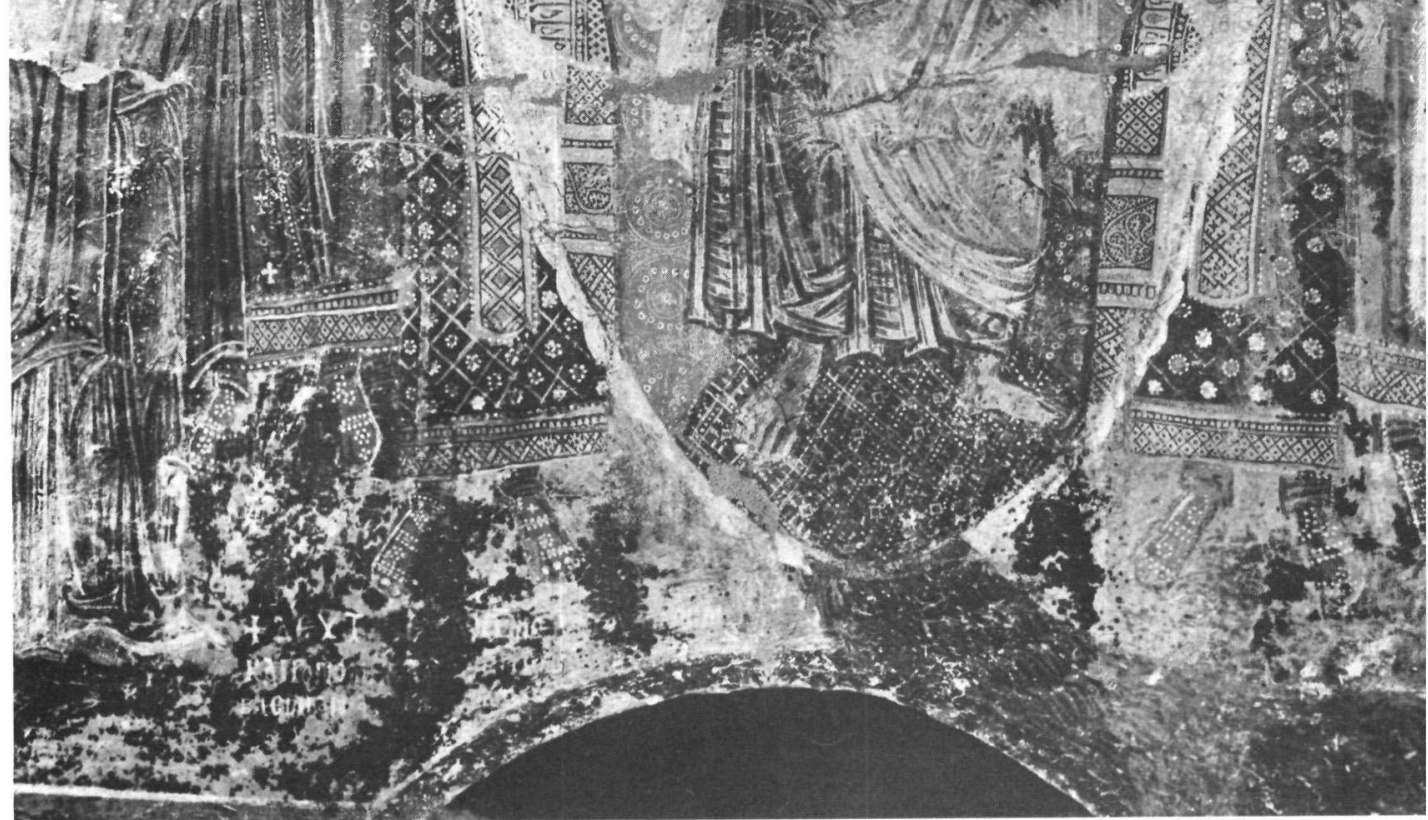




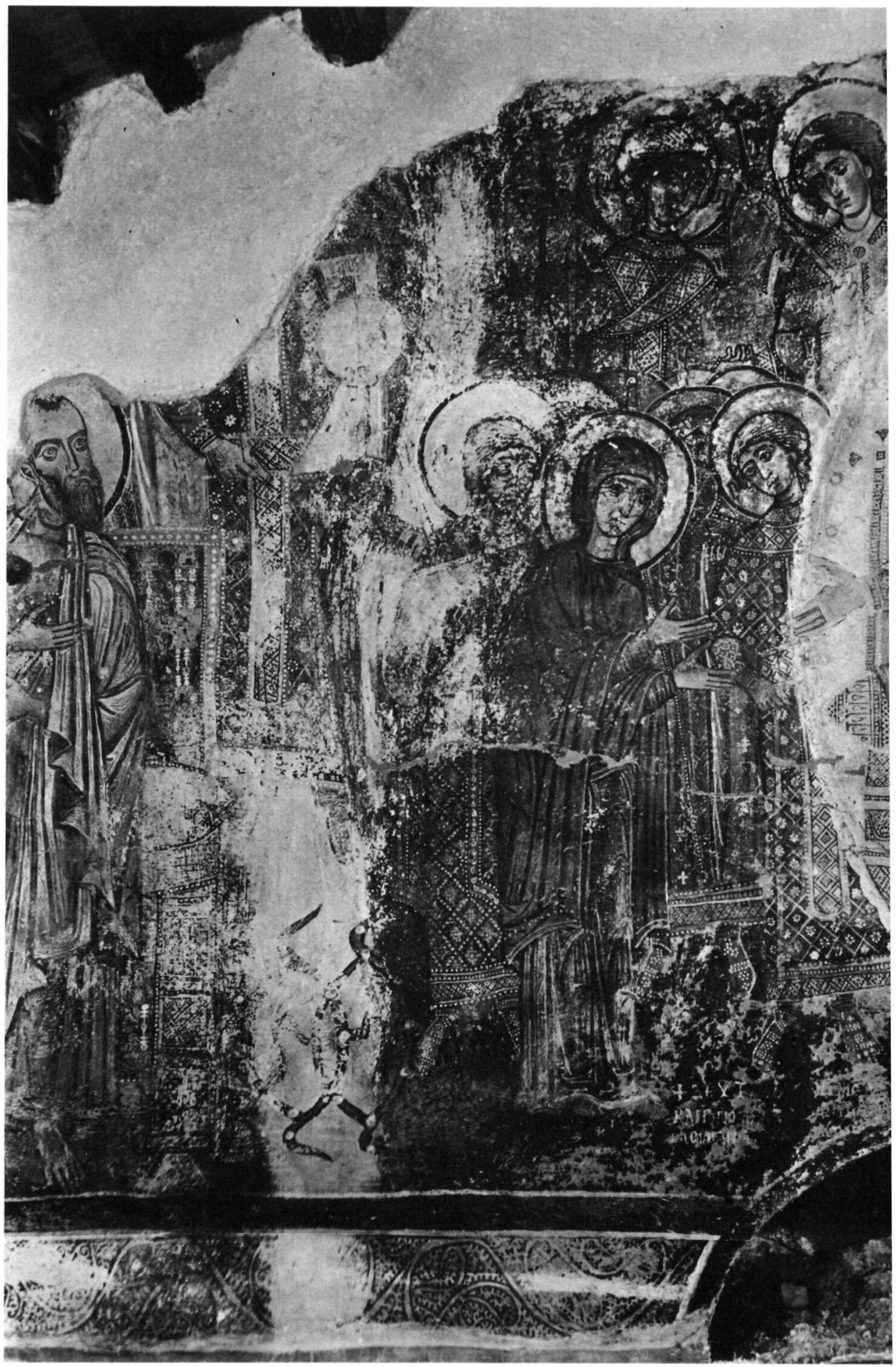




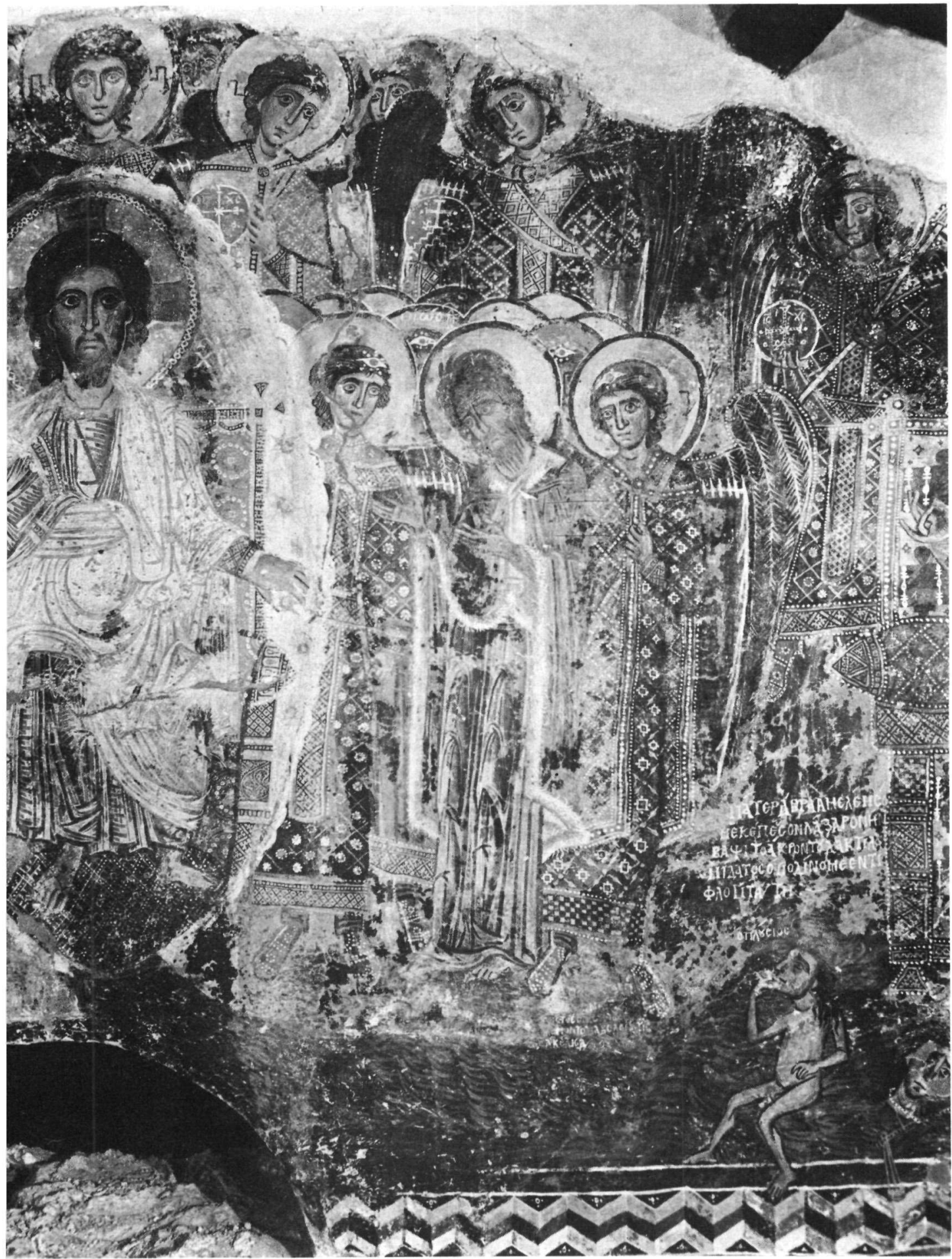
Last Judgment. 

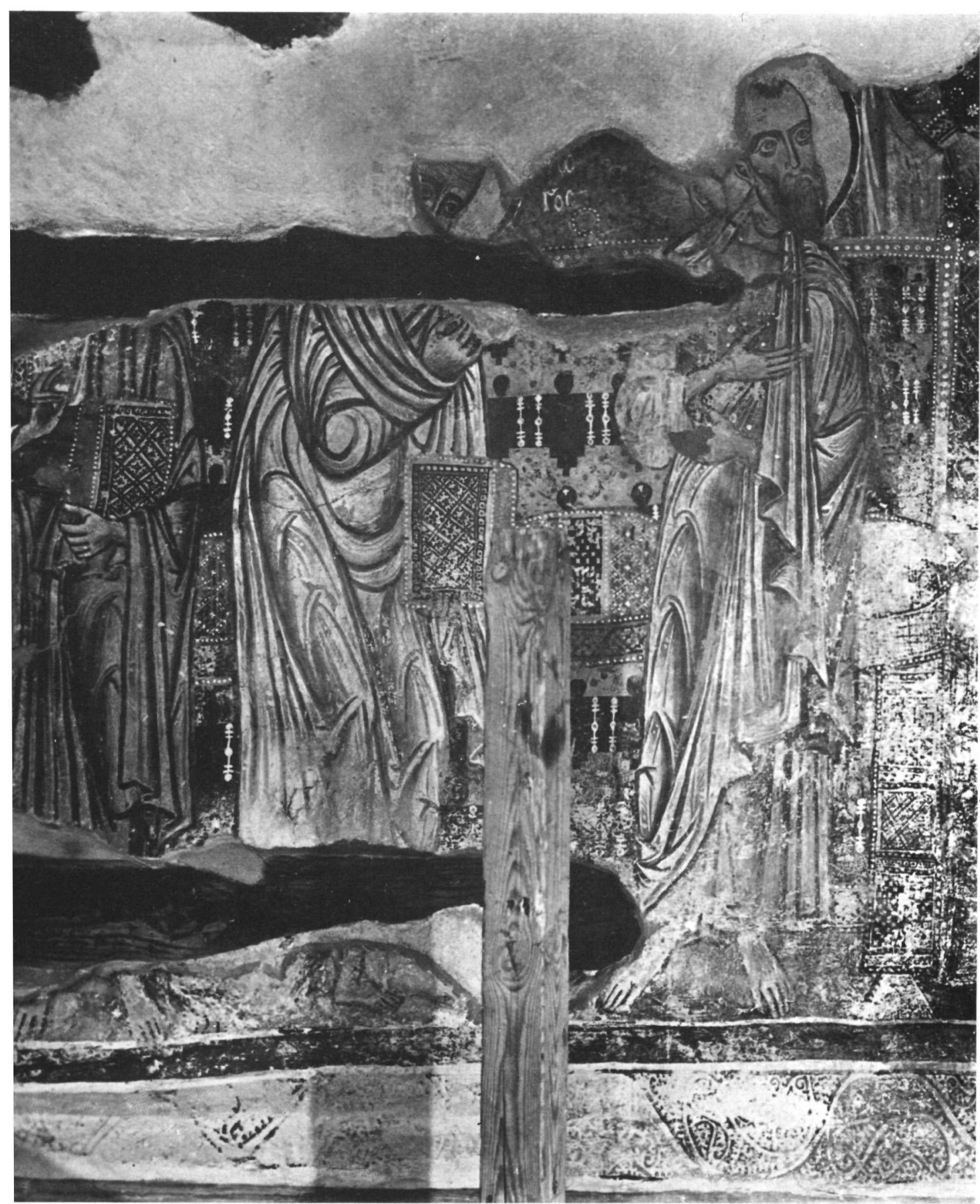

Last Judgment. Detail. 
W.

W.

19?

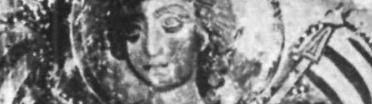

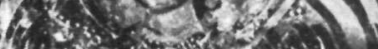

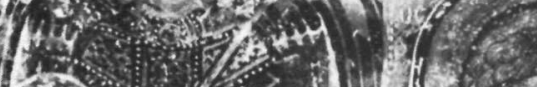

(9.) $8 \times 1$

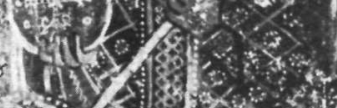

1. 13.06

$y+t^{2}$

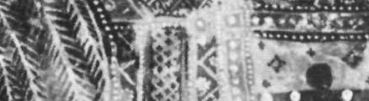

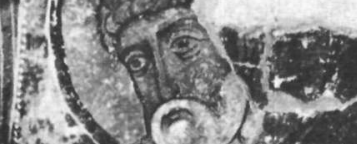

2. 918

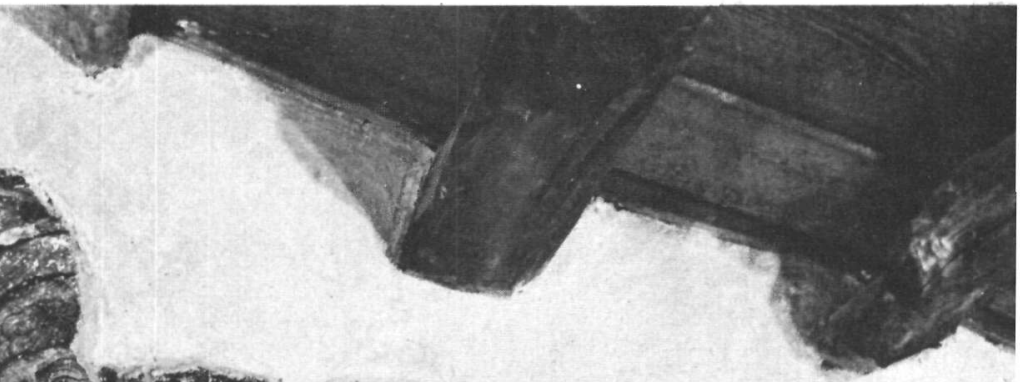

Y.

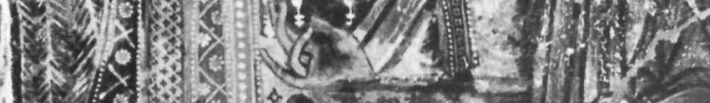

2.x.

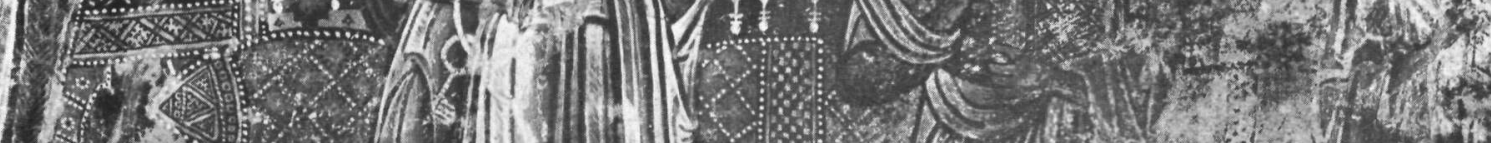

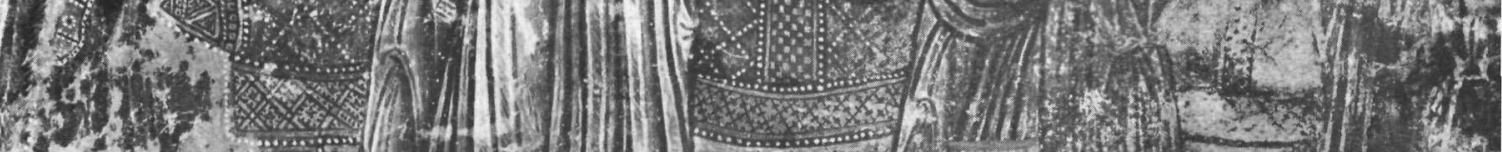
12. 10 tor

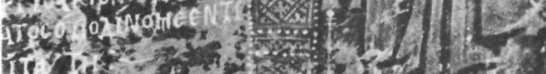

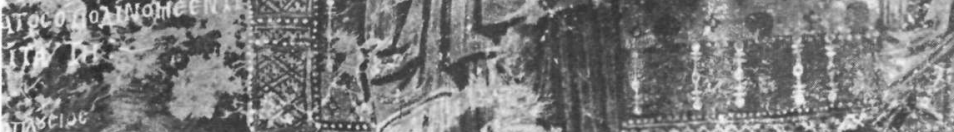

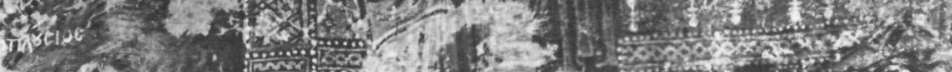

(6)

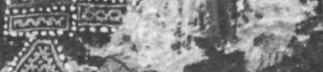

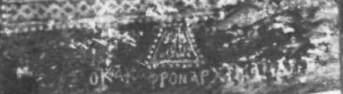
(1)

a

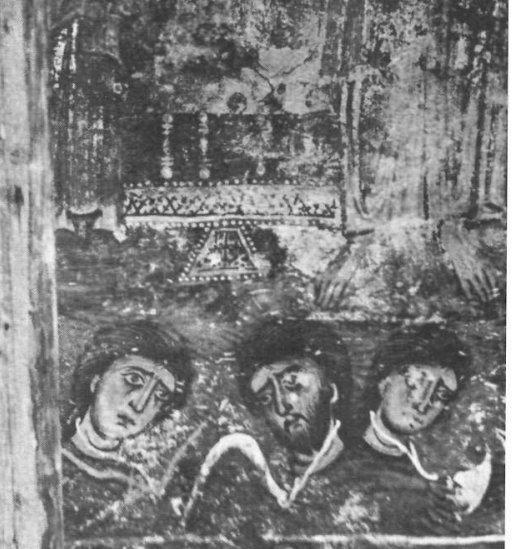

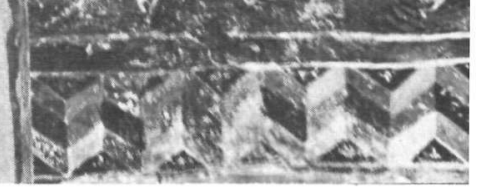

Last Judgment. Detail. 


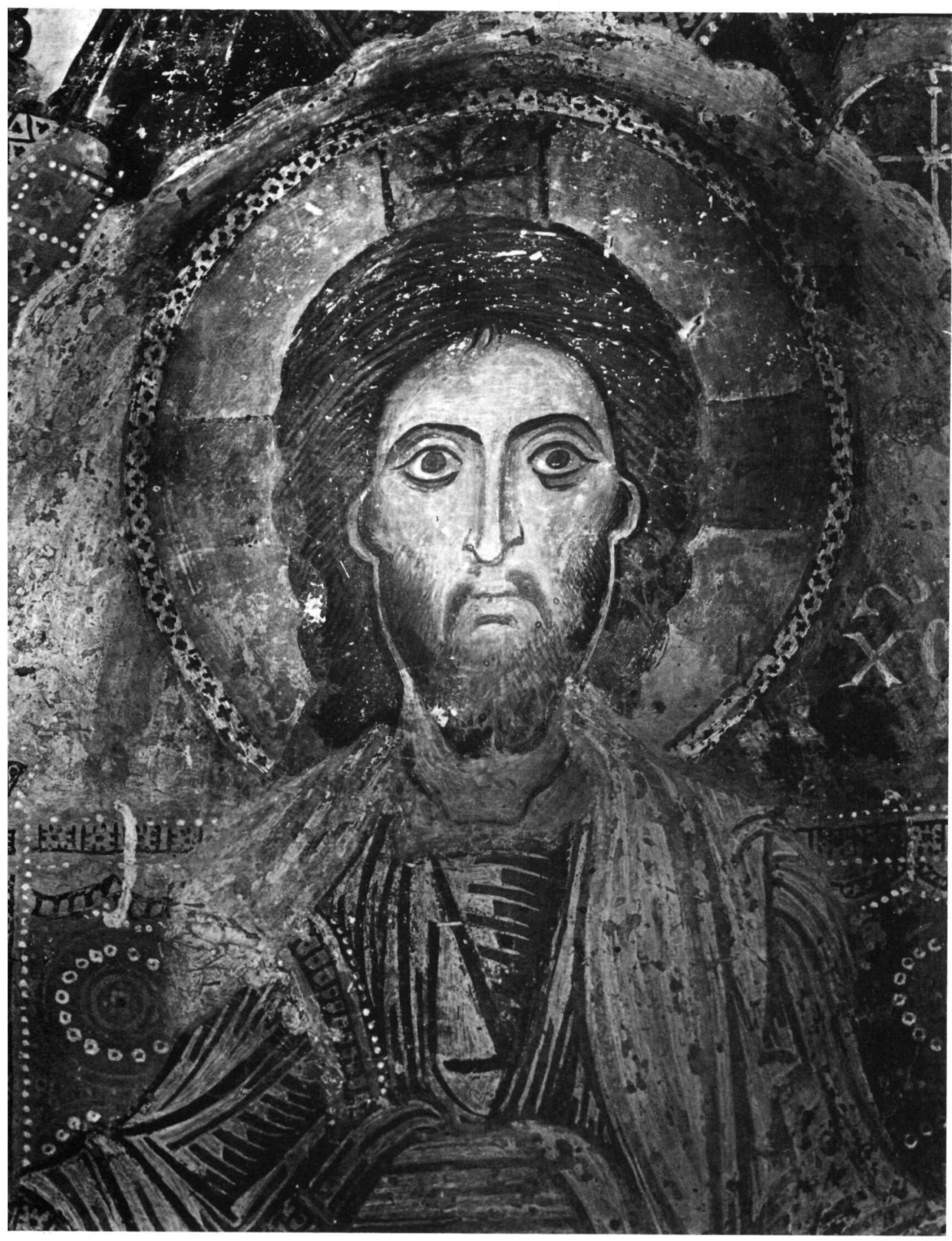




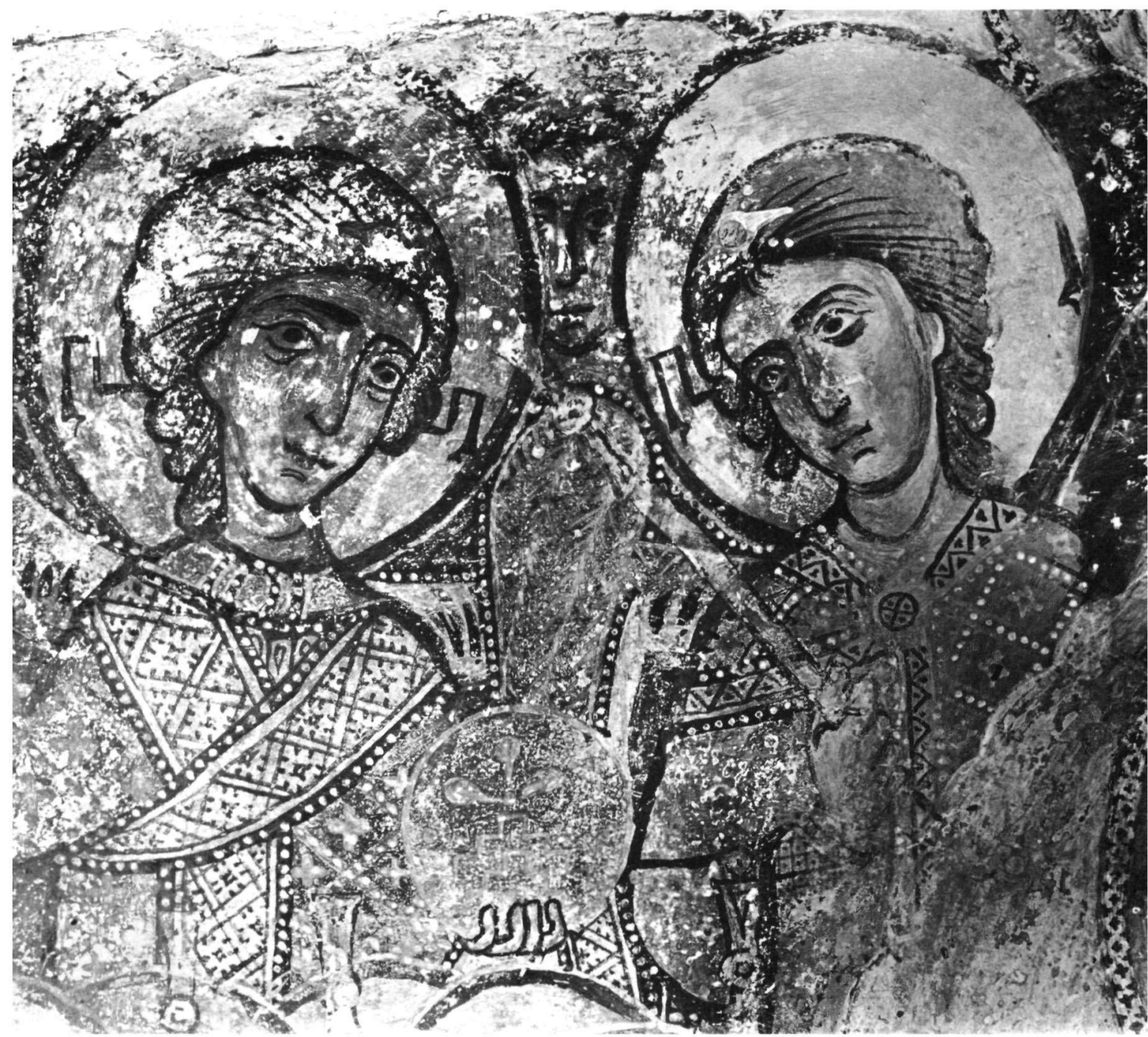

Last Judgment. Two angels (detail). 


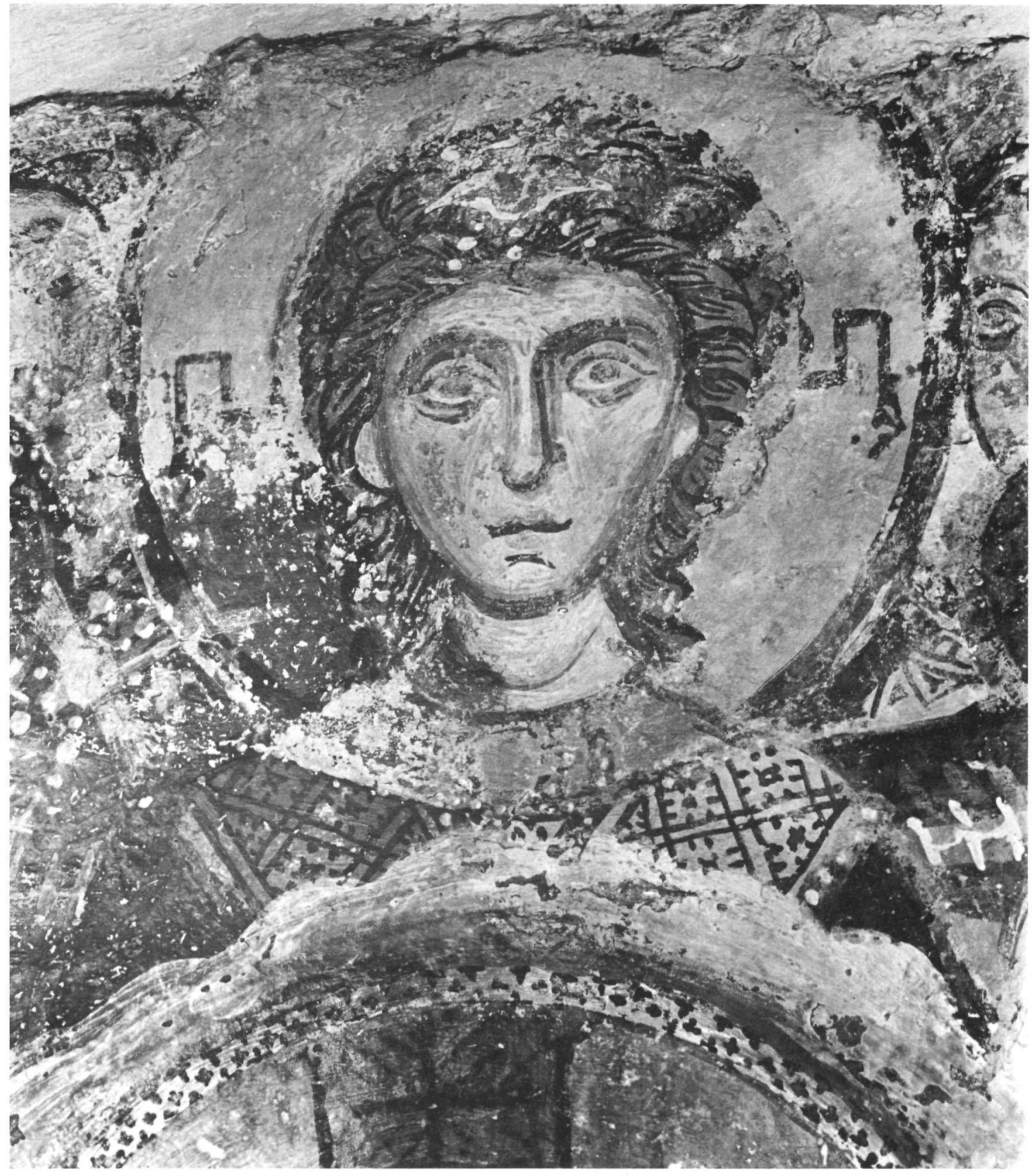

Last Judgment. An angel (detail). 


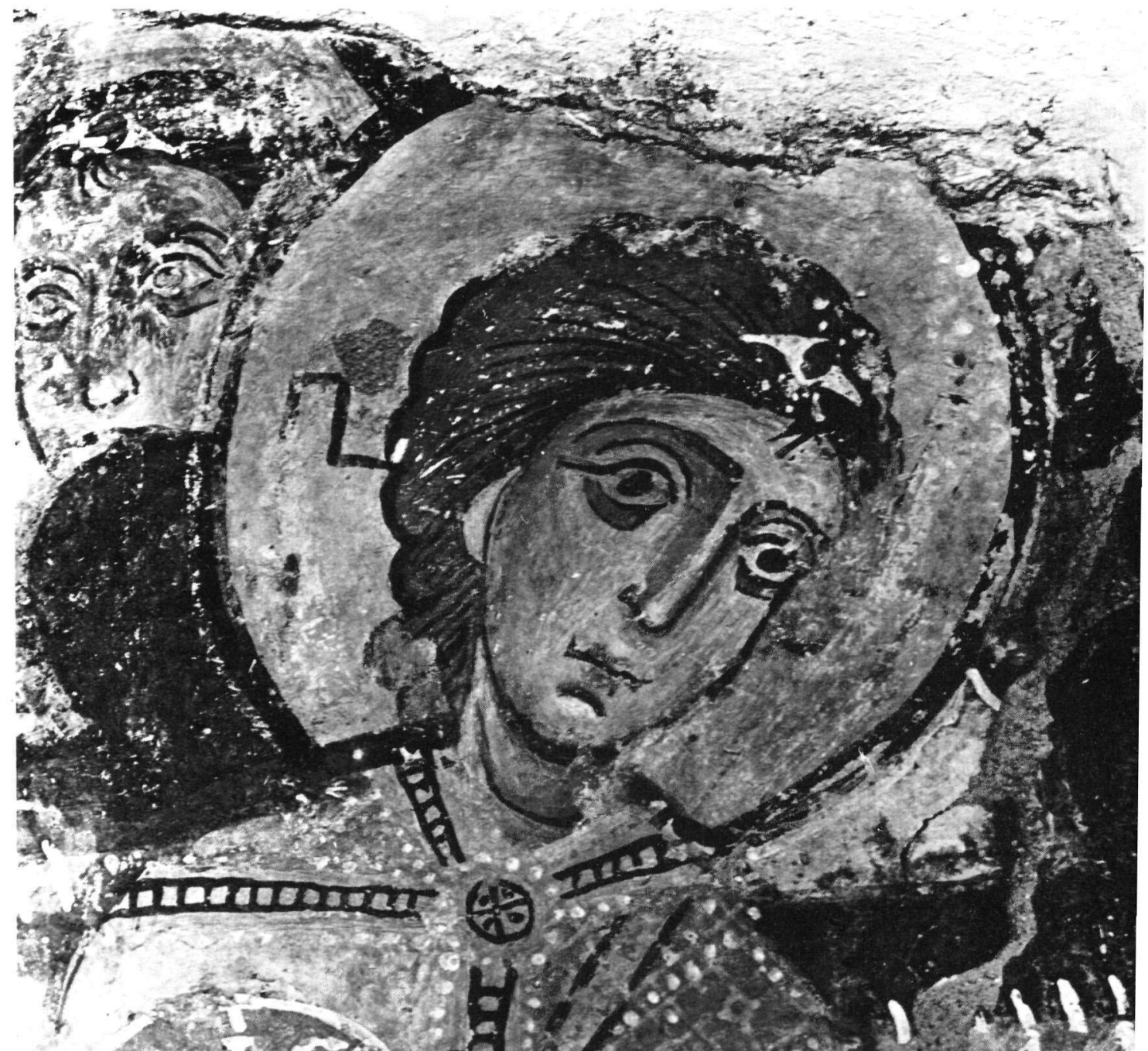

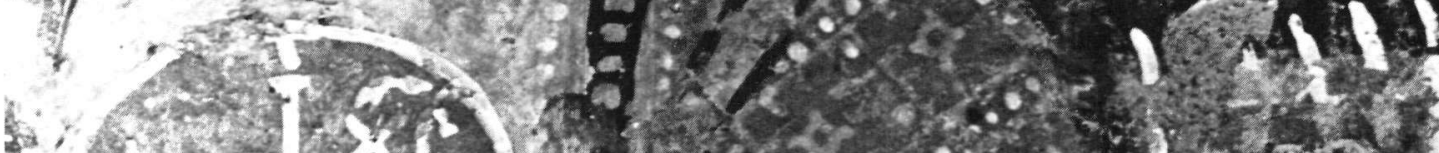
and Last Judgment. An angel (detail). 


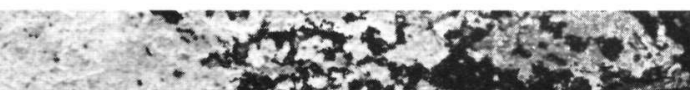

(n)

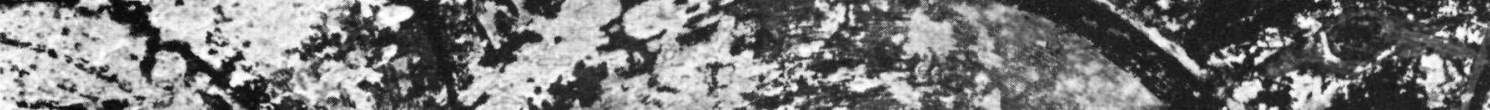

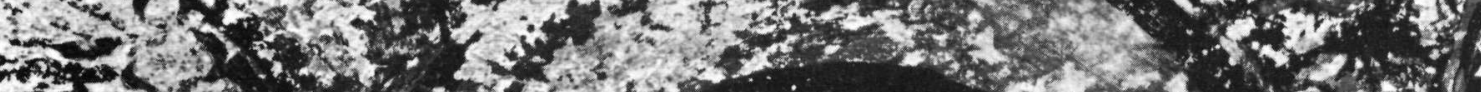

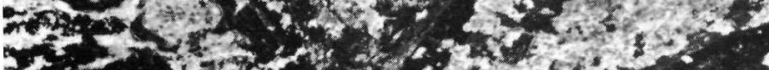

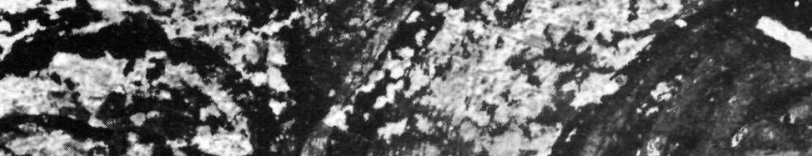

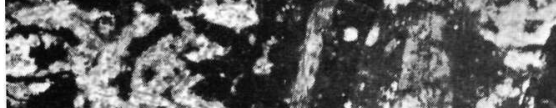

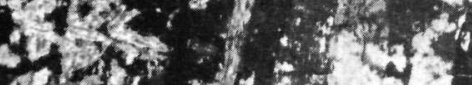

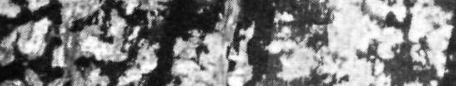
1.

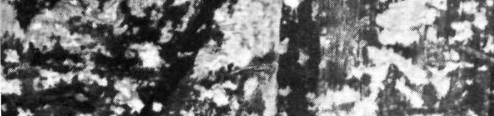

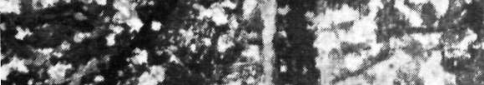
m.

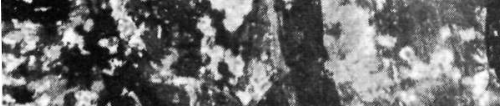

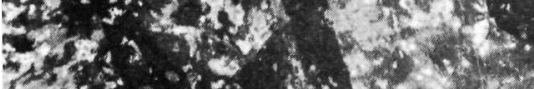

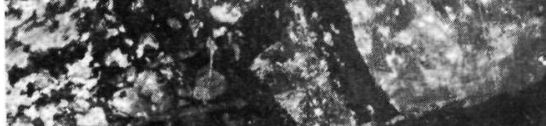

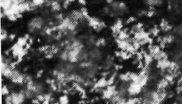

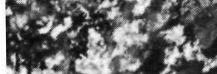

intw?

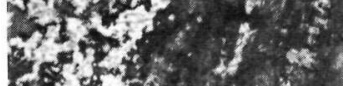

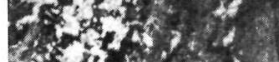

Coning:

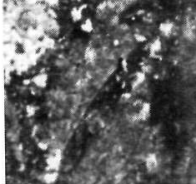

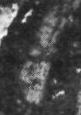

if $p$ at? -2.

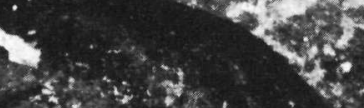

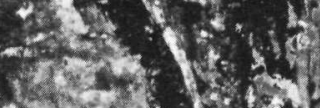
H. . 


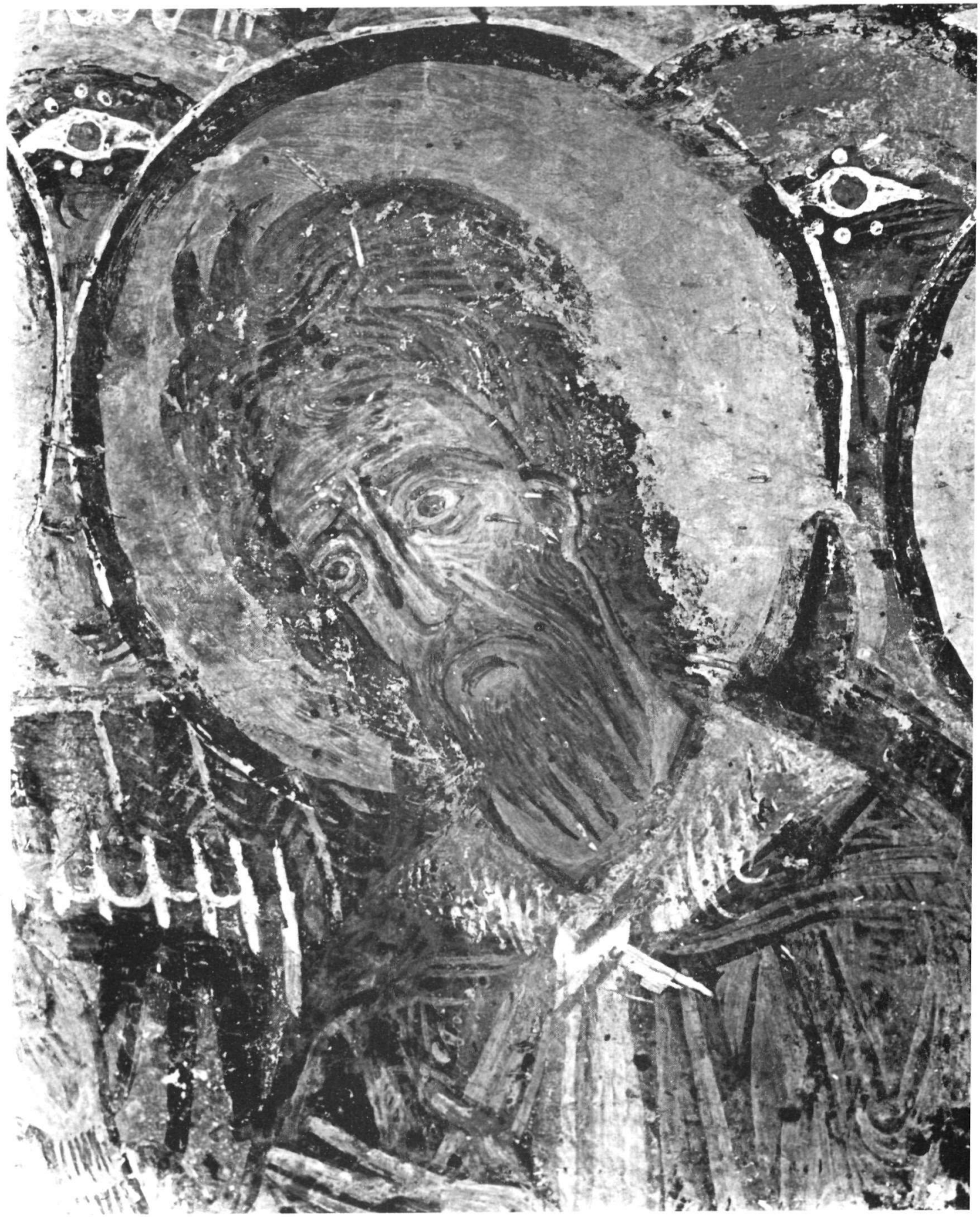

Last Judgment. St. John the Baptist (detail). 


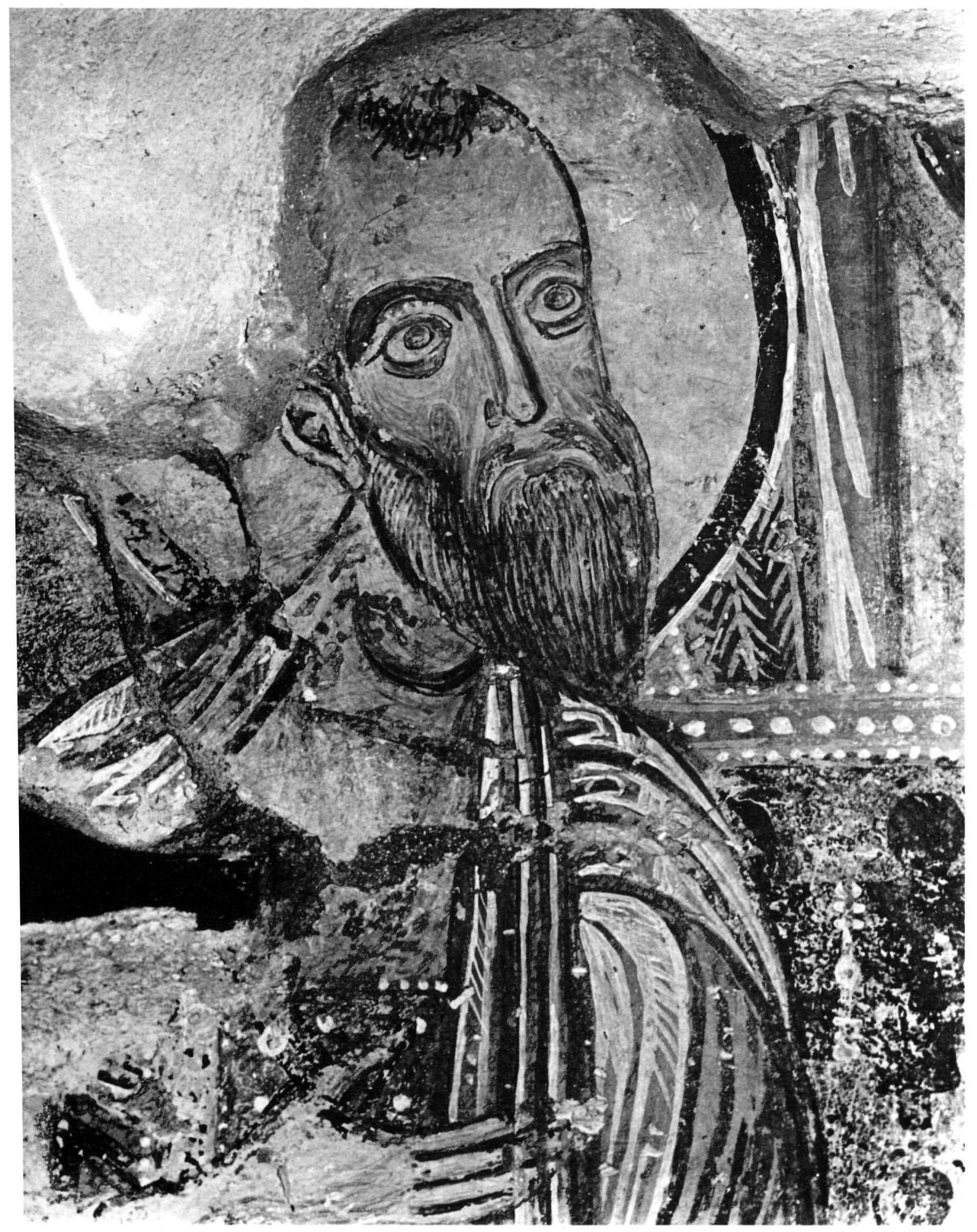

Last Judgment. St. Paul (detail). 


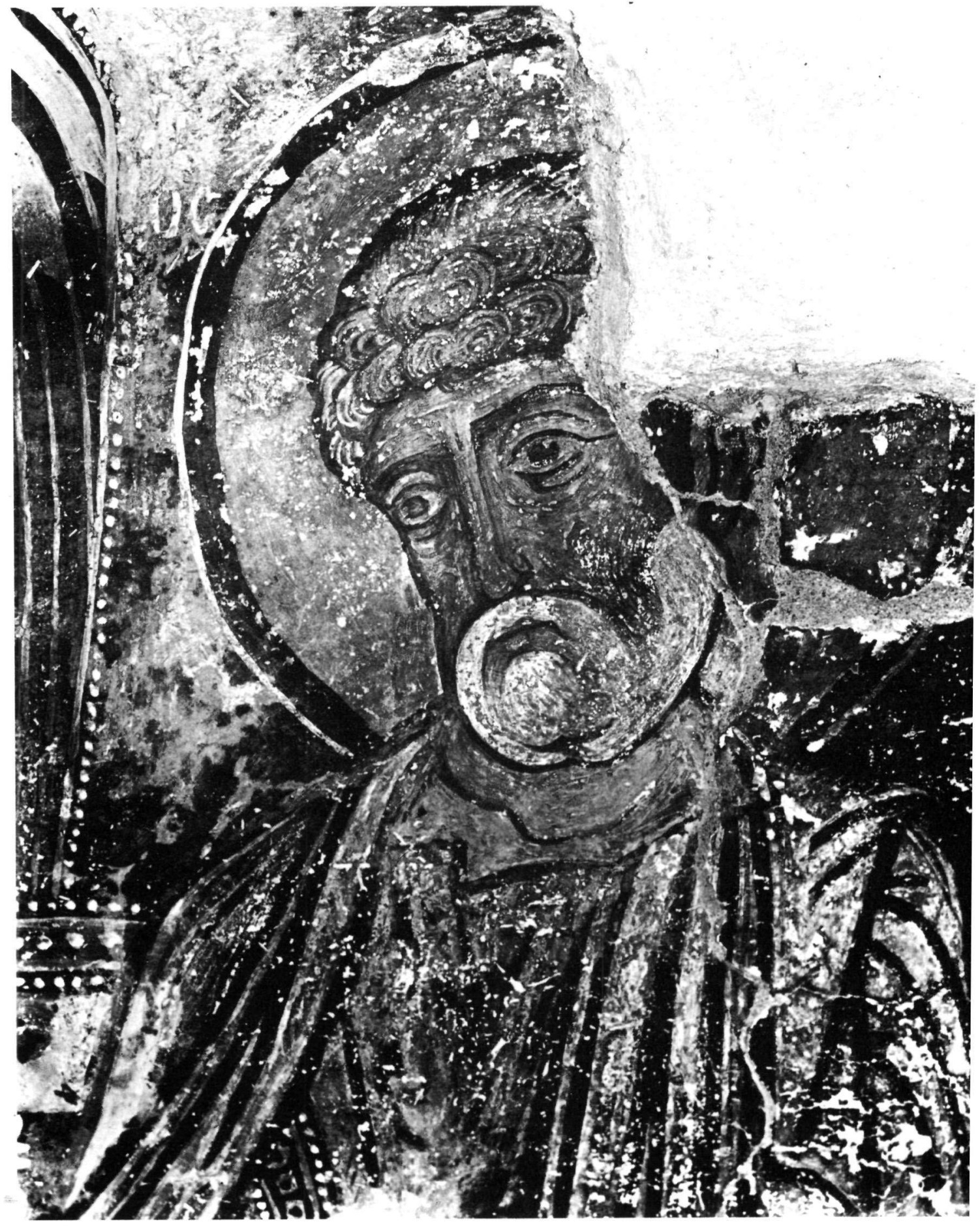

Last Judgment. St. Peter (detail). 


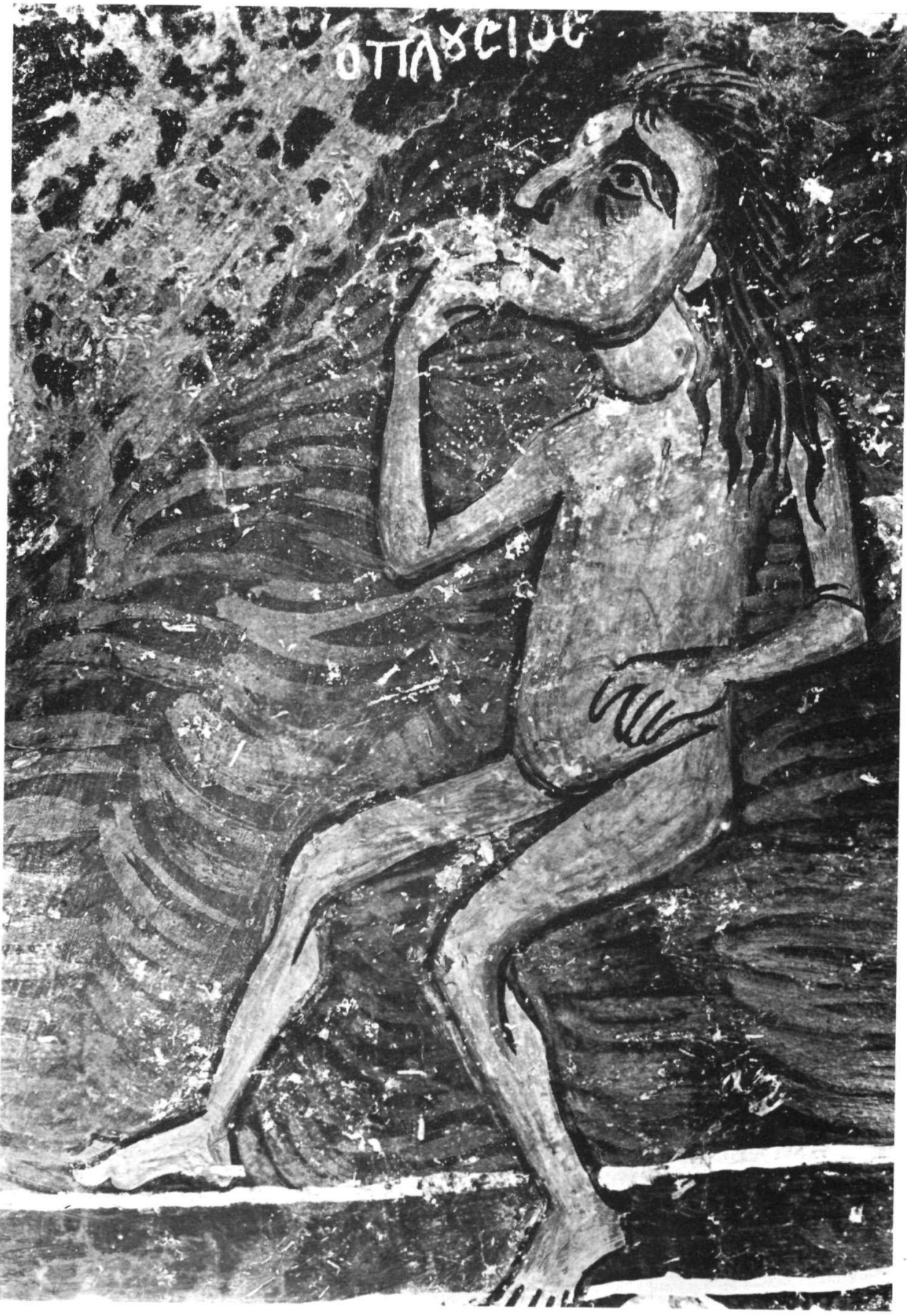

Last Judgment. The Rich Man. 


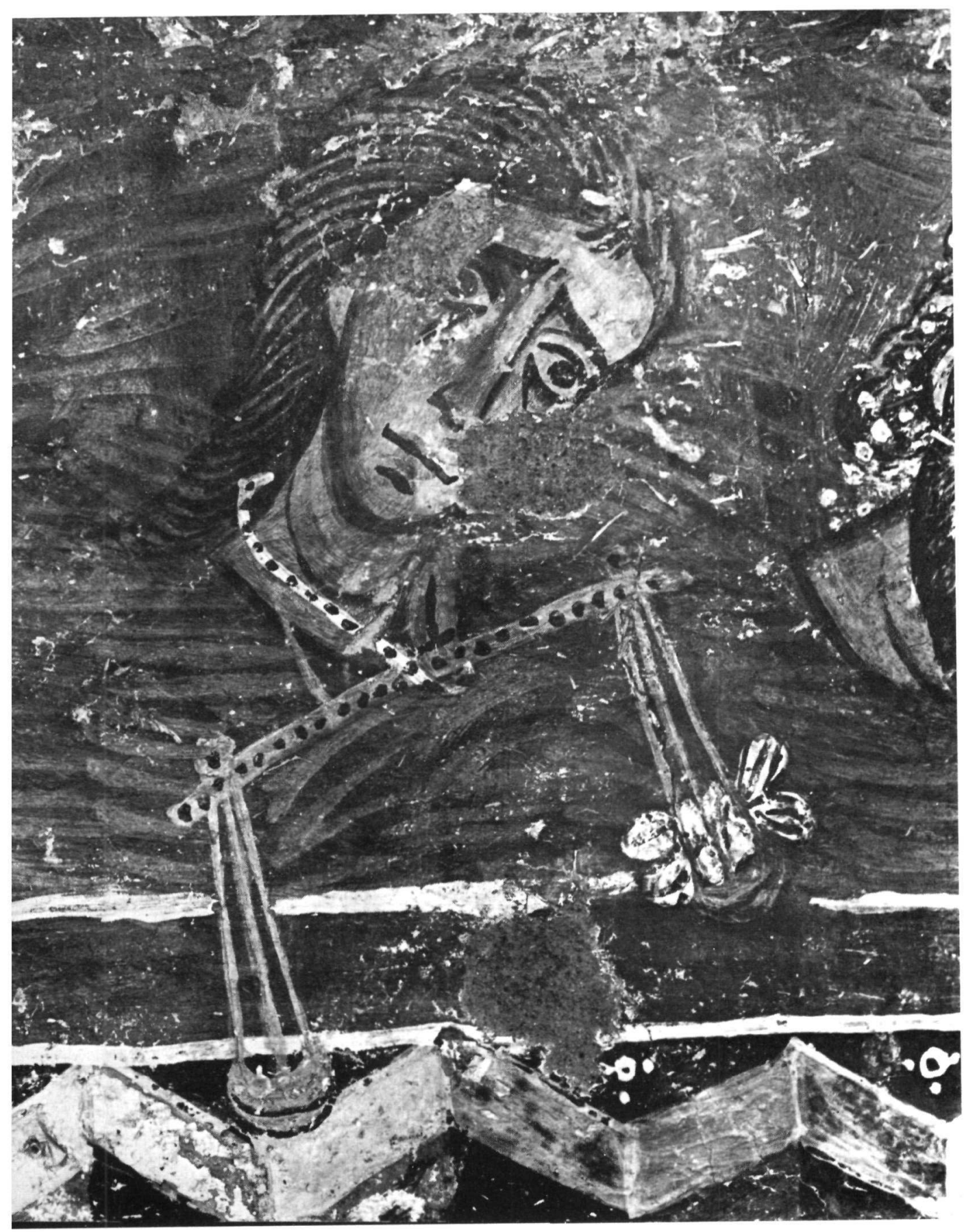

Last Judgment. The falsifier of weights. 


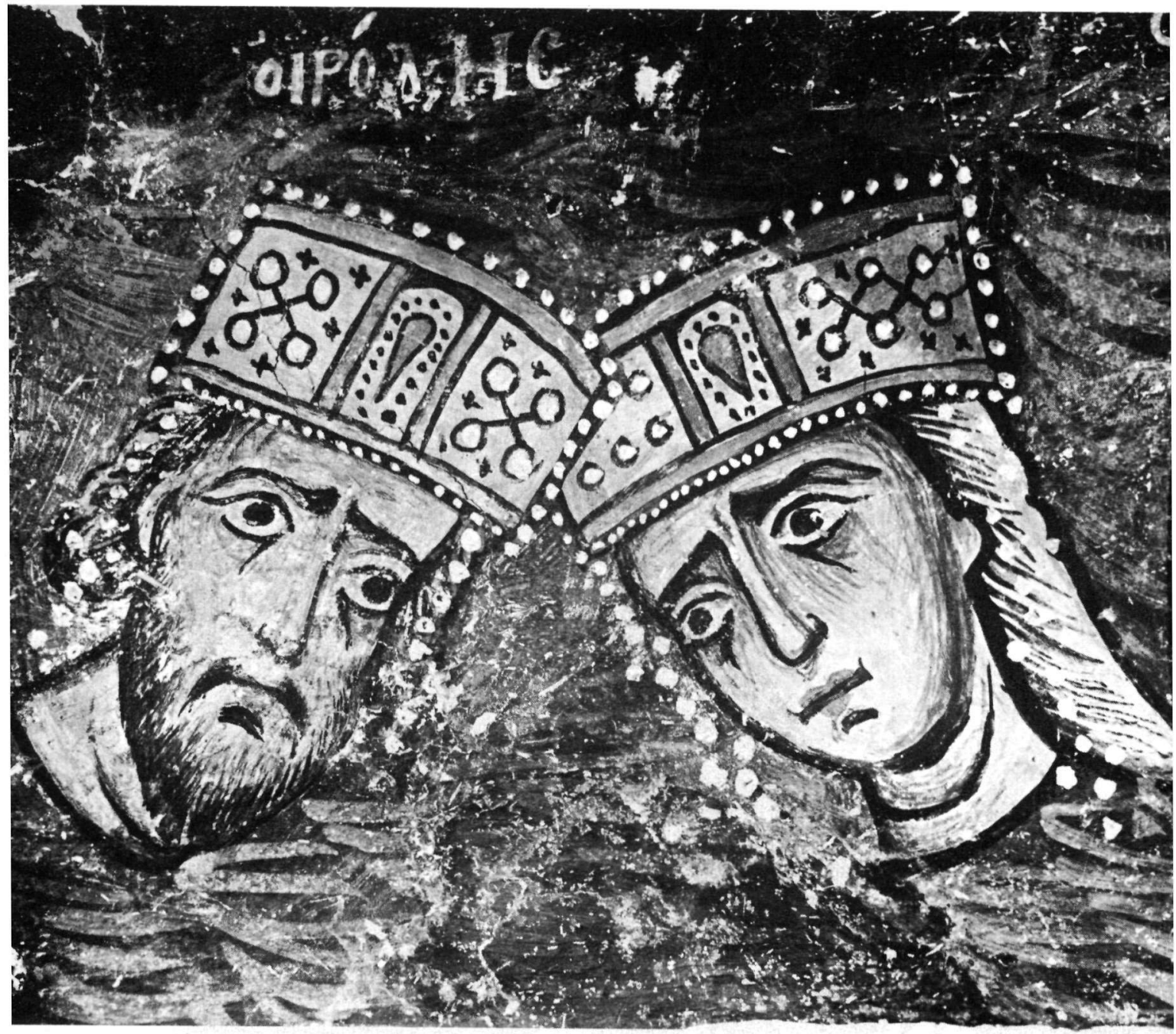

Last Judgment. Herod and Herodias. 


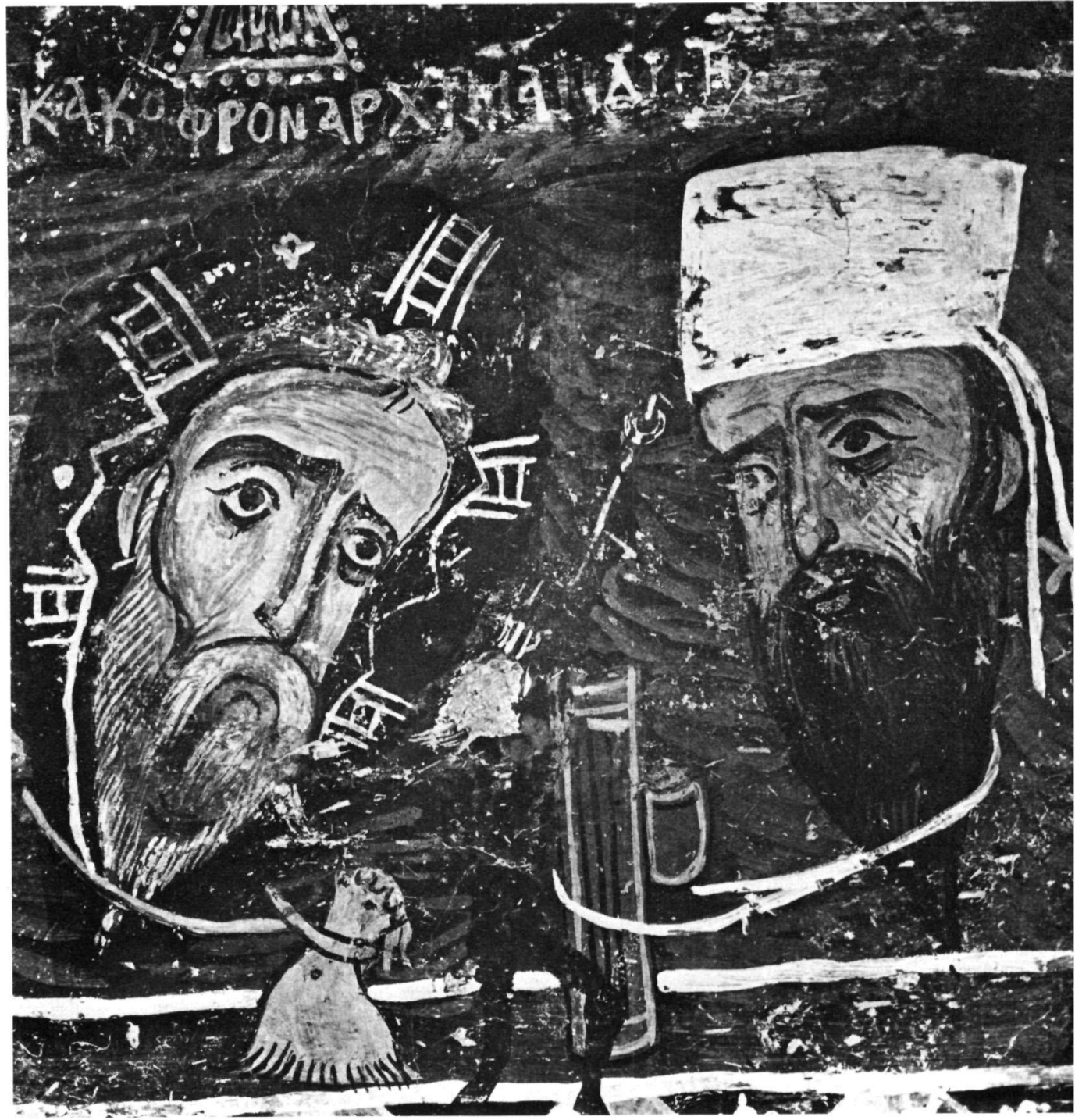

Last Judgment. Archimandrite and civil servant. 


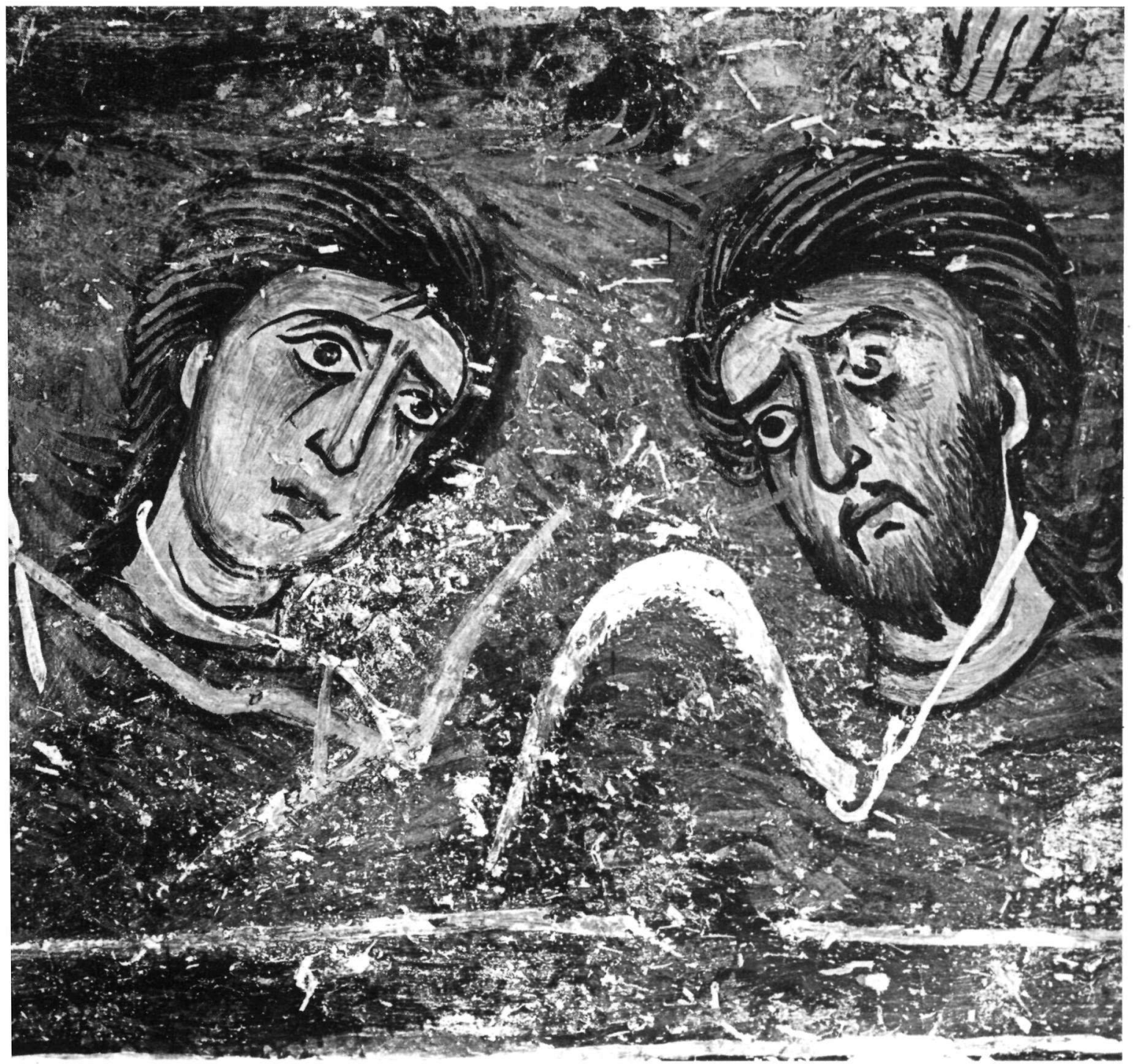

Last Judgment. Two men who respectively plough and harvest in another man's field 


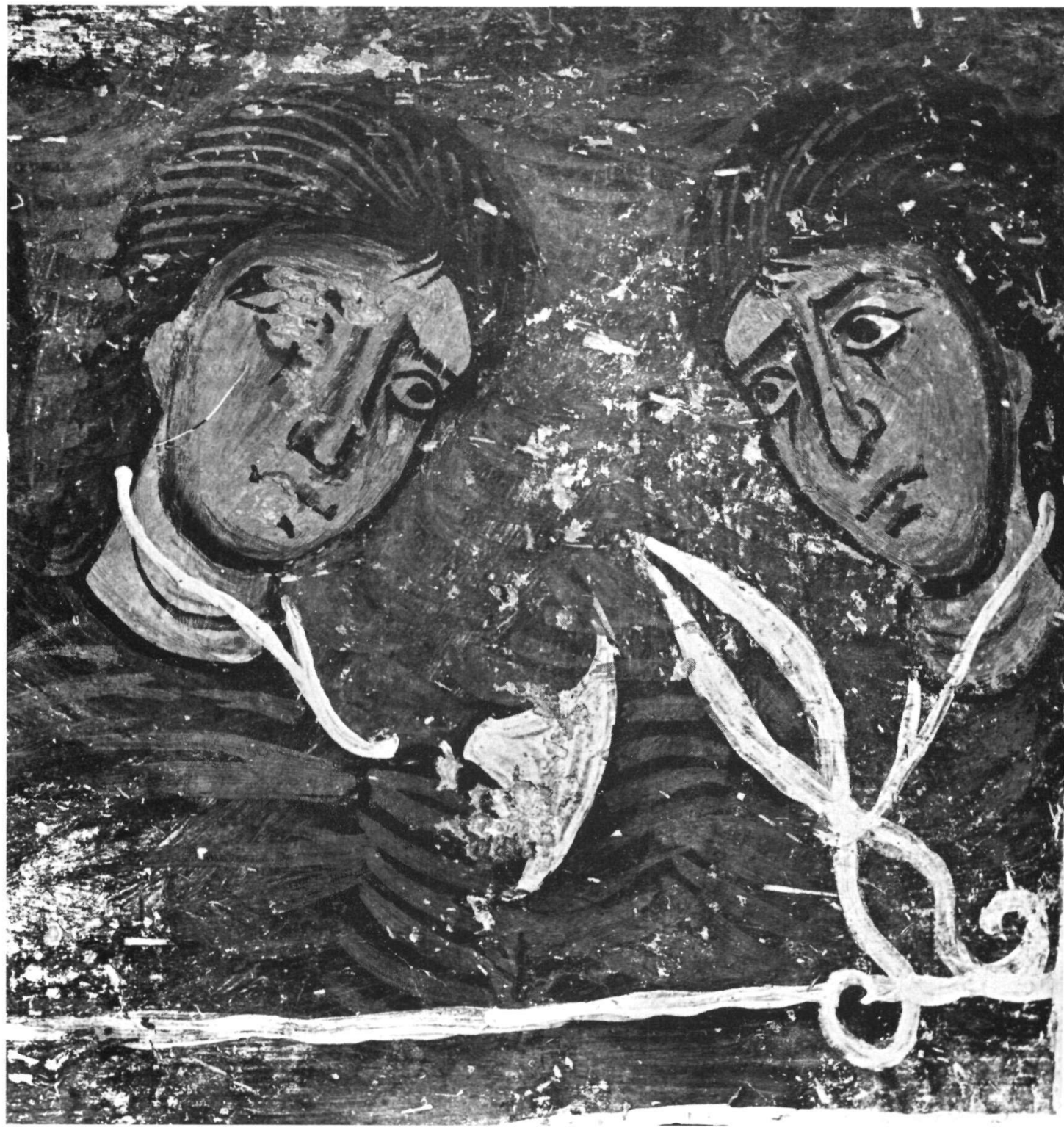

Last Judgment. Two men who cut respectively wood and branches in another man's property. 


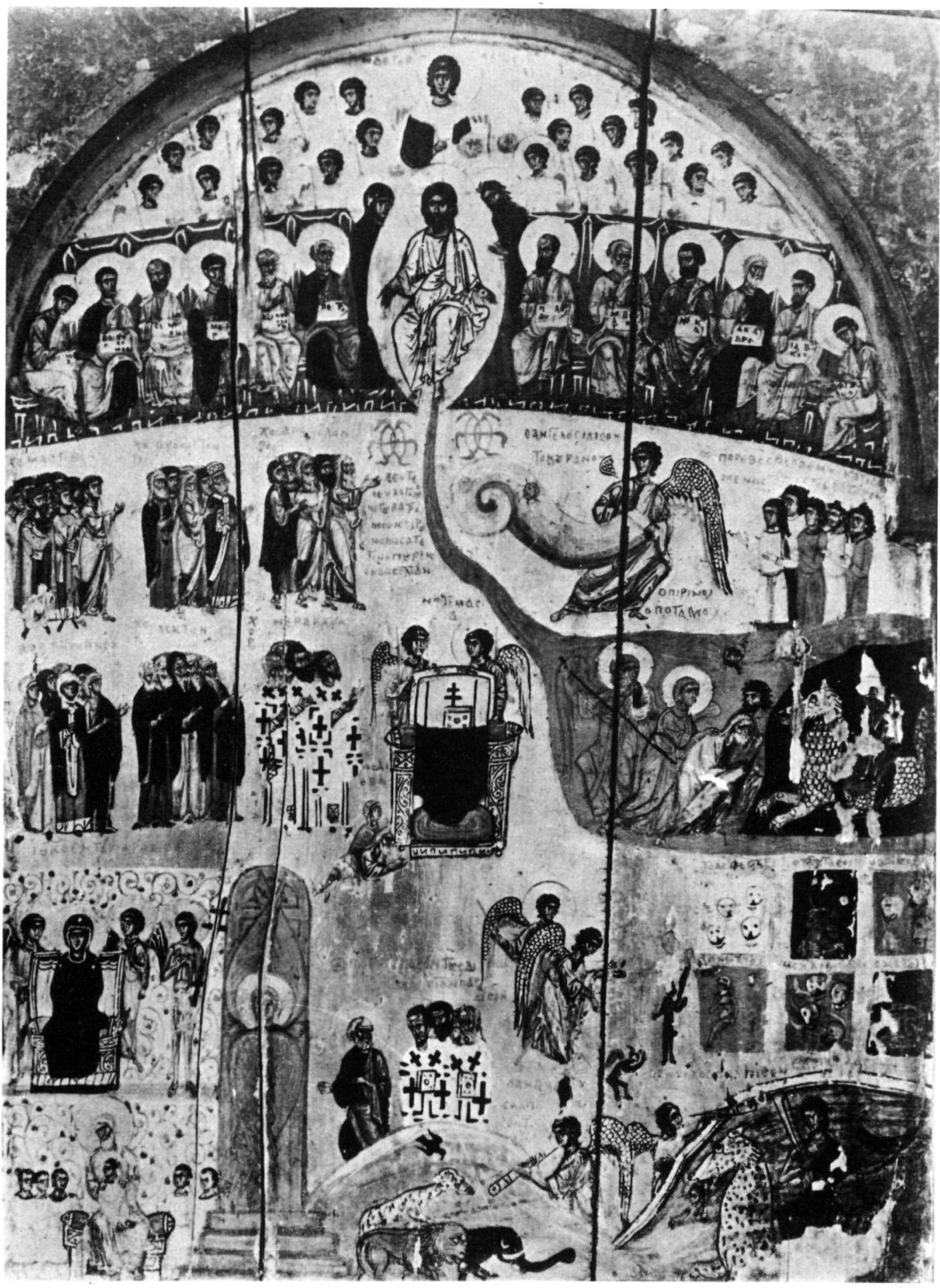

Last Judgment. Icon. Mount Sinai. 


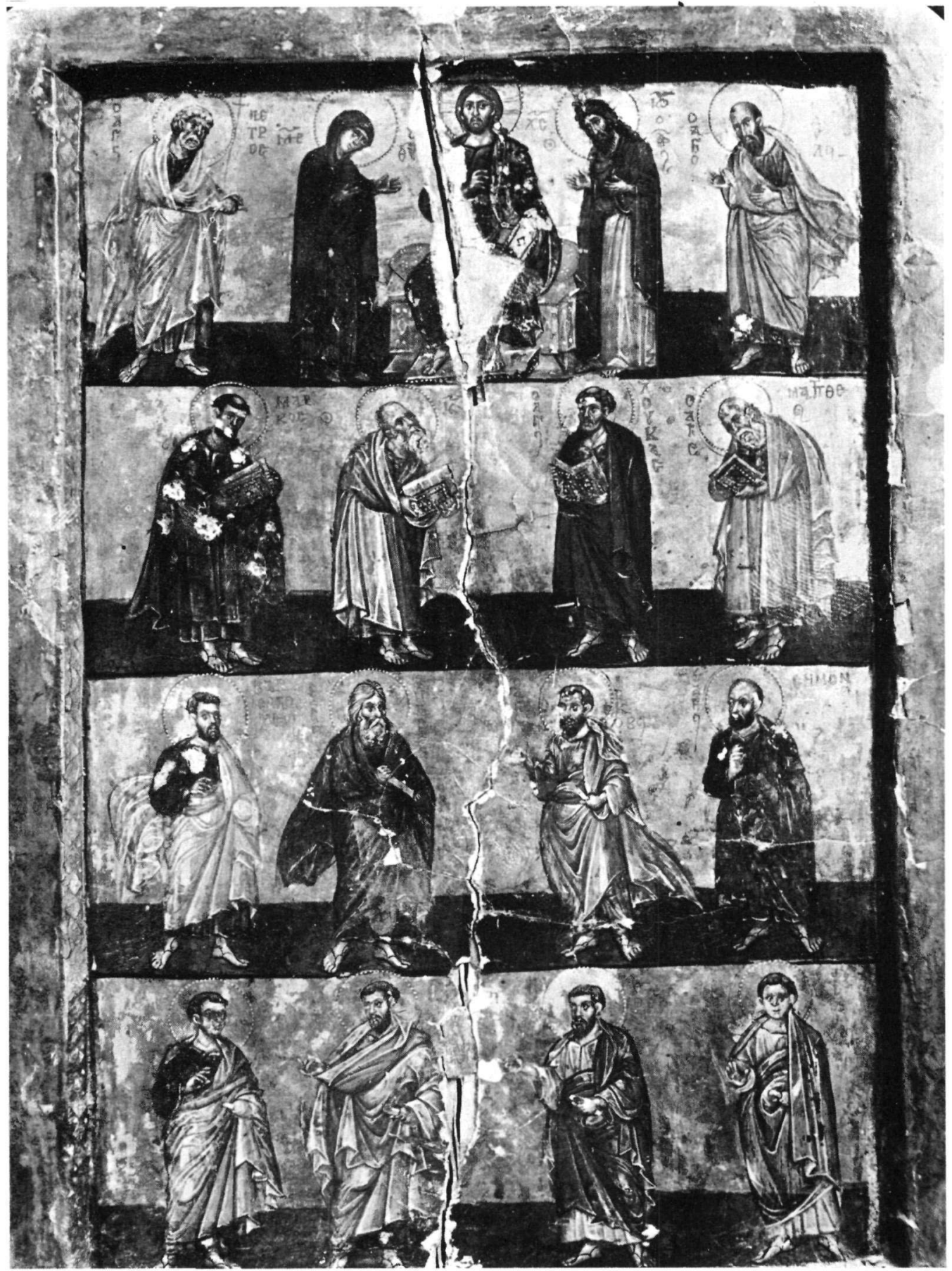

Great Deisis. Icon. Mount Sinai. 

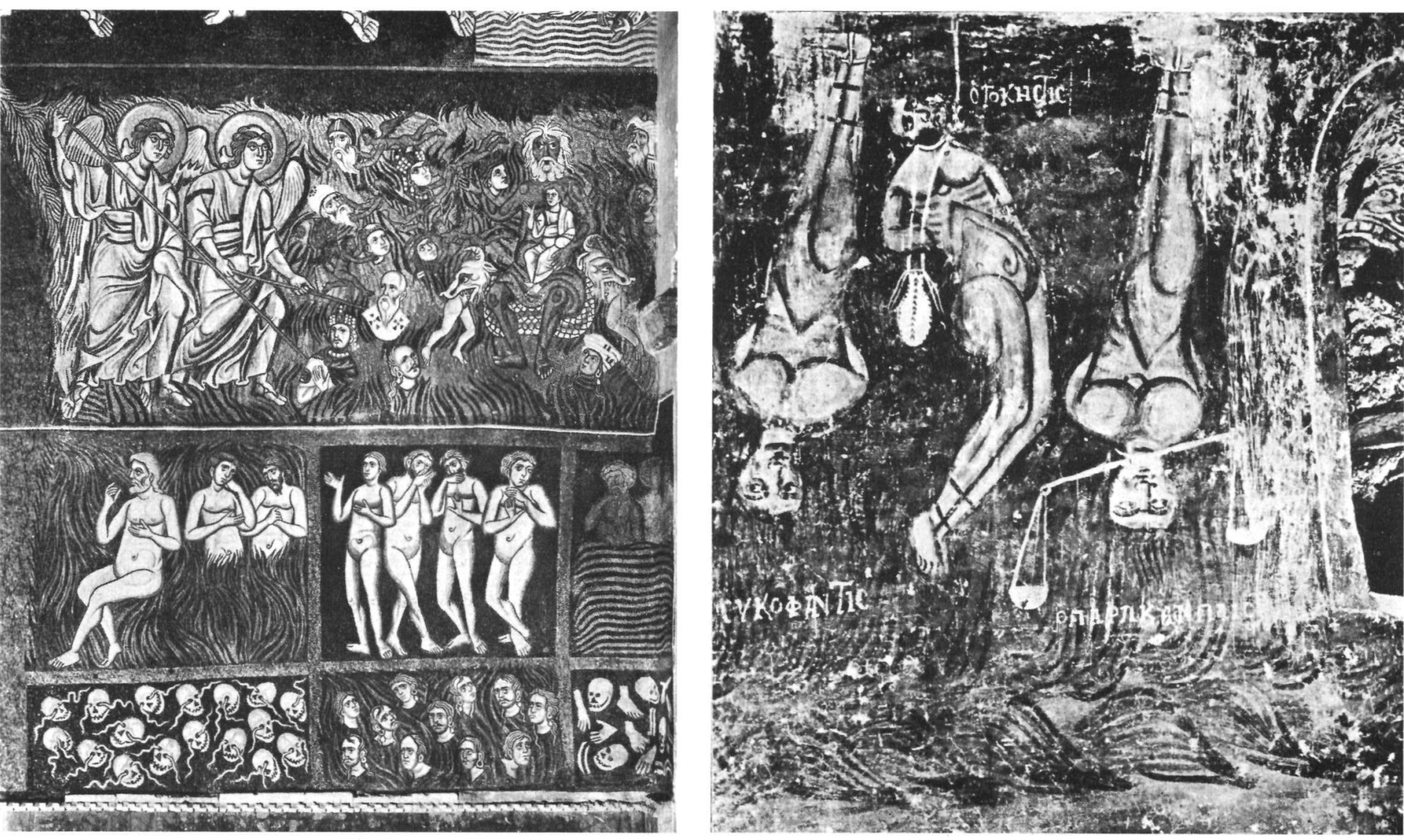

a. Last Judgment. The Damned in Hell. Detail of the mosaic at Torcello.

b. Last Judgment. The Damned in Hell. Detail of the fresco in the Mavriotissa at Castoria. 